Discussion Paper No. 14-066

\title{
Overleveraging in the Banking Sector: Evidence from Europe
}

Frauke Schleer, Willi Semmler, and Julian Illner

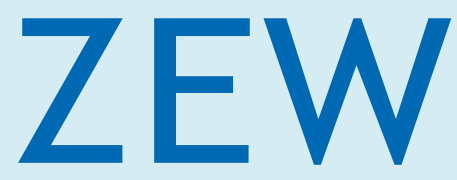

Zentrum für Europäische Wirtschaftsforschung $\mathrm{GmbH}$

Centre for European Economic Research 
Discussion Paper No. 14-066

\title{
Overleveraging in the Banking Sector: Evidence from Europe
}

\author{
Frauke Schleer, Willi Semmler, \\ and Julian Illner
}

Download this ZEW Discussion Paper from our ftp server:

http://ftp.zew.de/pub/zew-docs/dp/dp14066.pdf

Die Discussion Papers dienen einer möglichst schnellen Verbreitung von neueren Forschungsarbeiten des ZEW. Die Beiträge liegen in alleiniger Verantwortung der Autoren und stellen nicht notwendigerweise die Meinung des ZEW dar.

Discussion Papers are intended to make results of ZEW research promptly available to other economists in order to encourage discussion and suggestions for revisions. The authors are solely responsible for the contents which do not necessarily represent the opinion of the ZEW. 


\title{
Overleveraging in the Banking Sector: Evidence from Europe
}

\author{
Frauke Schleer*, Willi Semmler†, Julian Illner
}

September 21, 2014

\begin{abstract}
Overleveraging of the banking sector has been considered as one of the main causes of the 2007-09 financial crisis and the subsequent great recession. It was also of major concern for the subsequent BIS regulatory policies resulting in Basel III and its request for higher capital requirements. It has now become highly relevant for the planned European banking union. Overleveraging of the banking sector exposes the financial sector and the macroeconomy to vulnerabilities, but also, as critics state, seems to constrain credit flows to the private sector. We present here a measure of overleveraging, defined as the difference of actual and sustainable debt, conduct an empirical study on overleveraging for 40 banks in Europe, and study the vulnerabilities and credit contractions that can arise subsequently. Before the year 2004 overleveraging has not been a serious problem as leverage was on a sustainable level. However, in the run-up to the financial crisis, actual and optimal debt ran apart and the banking sector began to suffer from overleveraging. We use a nonlinear Vector STAR model to evaluate the hypothesis that periods of increasing debt levels are accompanied by more severe credit constraints than periods of low leveraging. We demonstrate this for country groups across Europe.
\end{abstract}

JEL classification: C61, E32, G01

Keywords: Overleveraging, banking sector, Vector STAR, real economy, credit flows, regime switch

\footnotetext{
${ }^{*}$ Centre for European Economic Research (ZEW), P.O. Box 103443, D-68034 Mannheim, Germany, Phone: +49/621/1235-164, E-mail: schleer@zew.de

†Corresponding author: Henry Arnhold Professor of Economics, New School for Social Research, 79 Fifth Ave., New York, NY 10003, USA, ZEW Research Associate, and currently visitor at the European Central Bank, Frankfurt, E-mail: semmlerw@newschool.edu
} 


\section{Introduction}

Excessive leveraging of the banking sector has recently become an crucial topic in economics. Many studies have demonstrated that the US financial crisis of the years 2007-09 was caused by excessive leveraging of the US banking sector, its exposure to the US real estate sector, and the highly non-linear amplification once the banking sector became vulnerable and inherently unstable after adverse shocks. ${ }^{1}$ Subsequently, in academic literature it has been hypothesized that an overleveraged banking sector leads to constraints in credit supply and recovery slows down. ${ }^{2}$

The regulatory proposals of Basel III in the years 2009 and 2010 also concentrate on the excessive leveraging of the banking sector, pointing to the fact that excessive leveraging makes the banking and financial sector fragile, exposing it to instability and macroeconomic amplification. The major remedy suggested by most of the initial proposals for macroprudential regulation consists of constraining excessive leveraging and building up capital buffers in the banking sector in good times to be used in bad times (see Basel Committee on Banking Supervision August 2010). The EU is currently designing a banking union to be overseen by the ECB. Excessive leveraging of EU banks appears to be a liability for the stability of the future banking union. In preparatory work, ECB researchers have begun studying the issue (see Clerc et al. 2014).

The role of excess leverage as a driving force for the instability in the financial-real linkage are studied in many DSGE models. Much of this work is based on the financial accelerator of Bernanke et al. (1999) which exhibits some mean reverting behavior. ${ }^{3}$ In other theoretical work, more distant to the DSGE model, a number of studies focus on how fragile balance sheets of banks and the financial sector are likely to be destabilizing rather than mean reverting. ${ }^{4}$ The asset price channel through which the banking system's instability is triggered has become essential in those studies. This is strongly stressed by studies such as Adrian and Shin (2009), Brunnermeier (2009), Brunnermeier and Sannikov (2014), Mittnik and Semmler (2013), and Stein (2012, 2003), to name a few.

In a very stylized view Brunnermeier and Sannikov (2014) focus on financial experts representing financial intermediaries. In their view it is a shock to asset prices which creates a vicious cycle through the balance sheets of the banks, contagion effects and macro feedback effects. They call it the volatility paradox. When volatility of asset prices is low, risk taking and borrowing occurs, but low volatility builds up instability. When prices of assets - held by banks - fall, and therefore their equity value and net worth fall, the margin requirements for borrowing on the money market rise, forcing financial intermediaries to take haircuts and to further de-lever to remain liquid. This, in turn, can lead to a fire sale of assets, further depressing asset prices, decreasing net worth and thus triggering an endogenous jump in volatility and risk for all, generating a downward spiral.

In Mittnik and Semmler (2013), the vulnerability of the banks and the downward insta-

\footnotetext{
${ }^{1}$ See Brunnermeier (2009) and Brunnermeier and Oehmke (2013).

${ }^{2}$ This view is, for instance, expressed by Admati and Hellwig (2013).

${ }^{3}$ The work by Bernanke et al. (1999) studies the asset price movements and the relation to credit flows, but leaves aside the leveraging dynamics of financial intermediaries.

${ }^{4}$ See Goodhart et al. (2012).
} 
bility is caused by the limited liabilities of decision makers in banks, improper incentive systems and lack of constraints imposed on financial intermediaries that allow for unrestricted growth of capital assets (through borrowing). ${ }^{5}$ On the other hand generous payouts with no "skin in the game" affect the risk taking, equity formation and leveraging of banks. Higher payouts, for instance, may induce an increasing risk taking behavior, as well as risk transfer, and generate higher (endogenous) aggregate risk and greater risk premia for all. In the first instance though, banks may have loan losses that might arise from defaults of firms, households, the foreign sector, or from sovereign debt. Banks are substantially affected by financial stress that is triggered by securities price movements, high risk premia and credit spread, possibly then exposed to strong downward feedback loops.

In Stein $(2012,2003)$ the destabilizing mechanism also results from a linkage between asset prices and borrowing. When assets held by the banking sector tend to be overvalued, banks enjoy capital gains beside the normal returns, and they start to become overleveraged as compared to optimally leveraged. This happens when financing costs for leveraging are low and capital gains are emerging which provides the banks with high net worth. Actual operating income of banks is then composed of normal returns and stochastic capital gains. Debt tends to rise with capital gains and excess returns on capital, generating excessive borrowing (see Stein 2012, Ch.4). This can hold as long as interest rates are low and credit spreads are small. In fact, empirical studies show that low interest rates and capital gains are often strongly negatively correlated. ${ }^{6}$ On the other hand, in Stein's view, if capital gains shrink or become negative and credit spreads rise, actual leveraging turns out to be far above optimal leveraging and the balance sheets of banks are rapidly deteriorating, triggering downward amplifying effects.

In all three theoretical approaches mentioned above excessive leveraging of the banking sector is the essential driving force. Such a phase often begins with a period of tranquility during which financial fragility may nonetheless build up - low or zero risk premia can still be observed however, as for example in the US from the 1990s to 2007. Implicitly, the present value and the net worth of banks will tend to become quite large, because there is no correction through a risk premium. ${ }^{7}$

When the borrowing bubble bursts and asset price and net worth fall, and risk premia and credit spread rise, reducing lending, borrowing and financial intermediation, the process reverses. Banking vulnerability and the actual reverse process will of course also depend on other co-variates, such as a sudden rise of the the interbank lending rate, repo rate, a jump in credit spreads, dissipating liquidity, rise of financial stress and adverse feedback loops from the macroeconomy to the banks' balance sheets. ${ }^{8}$ It is therefore not necessarily the overleveraging itself that triggers instability, but it is also the financial stress and adverse feedback loops from real activity to financial intermediaries amplifying this process. The

\footnotetext{
${ }^{5}$ This source of instability is also discussed in Brunnermeier and Sannikov (2014).

${ }^{6}$ See Stein (2012, Ch.5). During the real estate boom one could observe low interest rates, risk premia and discount rates. In turn, low discount rates may generate high asset prices and capital gains.

${ }^{7}$ To avoid this misperception, Stein $(2012,2003)$ suggests to make corrections by proposing to take the trends/drifts in capital gains and interest rates in such a model, that would better measure some debt capacity.

${ }^{8}$ For details of such measures of financial conditions and a constructed index, see Schleer and Semmler (2013).
} 
latter leads to a fall in banks' operating income, a fall in net worth and rising banking stress. Thus, it is eventually this type of banking-macro linkage that will unleash major amplifying forces, possibly triggering severe downswings. ${ }^{9}$ A major issue is then how overleveraging can be measured and tracked empirically so as to obtain early warning signs.

To undertake an empirical study on those issues, we introduce a new measure of overleveraging. If borrowing exceeds debt capacity this can be called excess leveraging. Debt capacity will be measured as sustainable or optimal debt. In our empirical work, we follow Stein $(2012,2003)$ and measure overleveraging as leveraging over and above optimal leveraging. We hereby can show that many banks in Europe became vulnerable to a banking crisis before the 2007-09 crisis and remained vulnerable afterwards. We use a non-linear Vector STAR model to evaluate the hypothesis that periods of high leveraging are accompanied by more severe credit and output constraints than periods of decreasing leveraging, and demonstrate this for country groups in Europe.

Since overleveraging and the running down of the banks' net worth appear as the major cause of the build up of vulnerability of banks and restricted credit flows, the issue of leveraging constraints ${ }^{10}$ and raising capital requirements for banks ${ }^{11}$ has been brought up by regulatory literature and also by Basel III. Such a regulatory policy is also planned to be enacted in the euro area after the banking union. Many models used for such regulatory purposes assume that both net worth and leveraging are measured by stocks. Then a certain percentage of assets can be defined as the bank's equity to provide a safety net for the depositors and creditors of the bank (Clerc et al. 2014). According to Basel III, the fraction of assets, possibly risk weighted assets, that is required to be held as the bank's capital, should be increased to $7 \%$ or $8 \%$ and even considerable higher in some proposals. $^{12}$

As Brunnermeier and Sannikov (2014), Stein (2012) and Mittnik and Semmler (2013) when studying overleveraging, we follow the above literature in the model variant set out here and start with a continuous time model. In contrast to Mittnik and Semmler (2013), Schleer and Semmler (2013), who work with non-linear finance-macro links, we, along the line of Brunnermeier and Sannikov (2014) and Stein (2012), employ stochastic processes in this paper. We will use a novel method called Non-linear Model Predictive Control (NMPC), as presented in Grüne and Pannek (2011) and Grüne et al. (2013), the latter using economic discounting.

The paper is organized as follows. Section 2 provides a dynamic model on optimal leveraging. Section 3 explains the methodology to empirically measure excess leveraging and reports the results on overleveraging for banks, countries, and country groups in Europe. Section 4 applies a regime-switching Vector STAR model to study effects of shocks in good and bad times of leveraging in the banking sector. Section 5 concludes. The appendices provide the solution method, derivation of optimal debt and detailed results on EU banks and countries.

\footnotetext{
${ }^{9}$ Recently such feedback loops have been discussed for the euro area where a triangle relationship between private borrowing, bank leveraging, and sovereign debt has been observed, see Brunnermeier and Oehmke (2013).

${ }^{10}$ See Christiano and Ikeda (2013).

${ }^{11}$ See Clerc et al. (2014).

${ }^{12}$ See Admati and Hellwig (2013) who argue for capital buffers of up to $30 \%$.
} 


\section{Theoretical model}

Next, we introduce a model of optimal leverage that helps us to define overleveraging. The model sketched here is a low-dimensional stochastic variant of a model of banking leveraging. A model like this can be found in Brunnermeier and Sannikov (2014, sect. I), and Stein $(2012,2003)$.

Brunnermeier and Sannikov (2014) apply a more general setting as used here. There are households that save and financial experts representing financial intermediaries that invest in capital assets owned by households and financial intermediaries. Both have different discount rates. The easier access of financial intermediaries to the credit market shifts, in the long run, the ownership of capital. In our model we will leave out the specifications of households, the dynamics of the capital stock, its changing ownership, and aggregate net worth. We focus solely on the behavior of financial intermediaries. Yet, overall, our model is very similar to Brunnermeier and Sannikov (2014) and Stein (2012, 2003). Both models have leveraging and payouts as a choice variable, and net worth as a state variable, the latter denoted by $x_{1, t}$ in equ. (2). Moreover, both models are stochastic.

In such a model for financial intermediaries and the derivation of their optimal leveraging, one uses preferences in the objective function and Brownian motions as state variables. The Stein (2012) model, assuming certain restrictions for preferences, for example log utility, allows to exactly compute excess leveraging, see Appendix B. In this section we focus on the solution of a prototypical stochastic dynamic version that displays the mechanism of optimal leveraging. In order to solve such a stochastic variant dynamically through a numerical procedure, for which we use NMPC, we need to stylize a stochastic shock sequence (see equ. (3)) representing another state variable.

In Stein (2012, Ch.4) the capital return is stochastic due to capital gains and the interest rate is stochastic as well. In Brunnermeier and Sannikov (2014) only the capital return is stochastic at first. The interest rate is taken as constant, but later changed referring to time varying borrowing cost reflecting the expenses for screening and monitoring. Note also that whereas the Brunnermeier and Sannikov (2014) model is an infinite horizon model, the Stein (2012) model is designed for a finite decision horizon.

Both, Brunnermeier and Sannikov (2014) and Stein (2012) employ a continuous time version, but we formulate the problem as a discrete time variant with a discounted instantaneous payout $c_{t}$ and an optimal leveraging $f_{t}$ in $(1)-(3) .{ }^{13}$ The state variables are given by (2), and the stochastic shock process in equ. (3). We model this as a finite horizon decision problem, with decision horizon of $N$, in discrete time, as:

\footnotetext{
${ }^{13}$ In Brunnermeier and Sannikov (2014), in their equ. (7), net worth $n_{t}$ is their state variable, and $x_{t}$ and $d c_{t}$ are their decision variables, which are equivalent to $x_{t}=1+f_{t}$ and $d c_{t}=c_{t} x_{1, t}$ in our model. Also to be noted, Brunnermeier and Sannikov (2014) include another equation for the evolution of capital stock arising from a decision variable of investors. We neglect this aspect here, to focus, as Stein, on the net worth dynamics. Including the additional decision and state variable would make the Brunnermeier and Sannikov (2014) model again similar to the model of Mittnik and Semmler (2013), except in Brunnermeier and Sannikov (2014) leveraging is a choice variable.
} 


$$
V=\max _{c_{t}, f_{t}} E_{t} \sum_{t=0}^{N} \beta^{t} U\left(c_{t} x_{1, t}\right)
$$

s.t.

$$
\begin{gathered}
x_{1, t+1}=x_{1, t}+h x_{1, t}\left[\left(1+f_{t}\right)\left(y+\nu_{1} \ln x_{2, t}+r\right)-\left(i-\nu_{2} \ln x_{2, t}\right) f_{t}-a \varphi\left(x_{1, t}\right)-c_{t}\right] \\
x_{2, t+1}=\exp \left(\rho \ln x_{2, t}+z_{k}\right)
\end{gathered}
$$

Hereby $c$ and $f$ are the two decision variables, with $c=C / x_{1}$, and $f=d / x_{1}, d$ denoting debt, $h$ is the step size, $y$ denotes capital gains, driven by stochastic shocks, $\nu_{1} \ln x_{2, t}$. The return on capital is $r, i$ the interest rate, also driven by stochastic shocks, $\nu_{2} \ln g x_{2, t}{ }^{14}$, $a \varphi\left(x_{1, t}\right)$ are convex adjustment costs, $\rho$ is a persistence parameter, with $\rho=0.9$, and $z_{k}$ is an i.i.d. random variable with zero mean and a variance, $\sigma=0.05$. We solve the model (1)-(3) through a stochastic version of NMPC, see Appendix A.

Figure 1 presents the path of the payout $c_{t}$ (red line) and leveraging $f_{t}$ (blue line). Note that we solve here only for optimal leveraging. As can be observed, the stochastic capital gains and interest rates generate a volatility of both payout and leveraging. Yet, the payout fluctuates roughly with the leveraging. In such a model, both Brunnermeier and Sannikov (2014) and Stein (2012) assume that in each period the debt is redeemed and, without cost, frictionless re-obtained on the market.

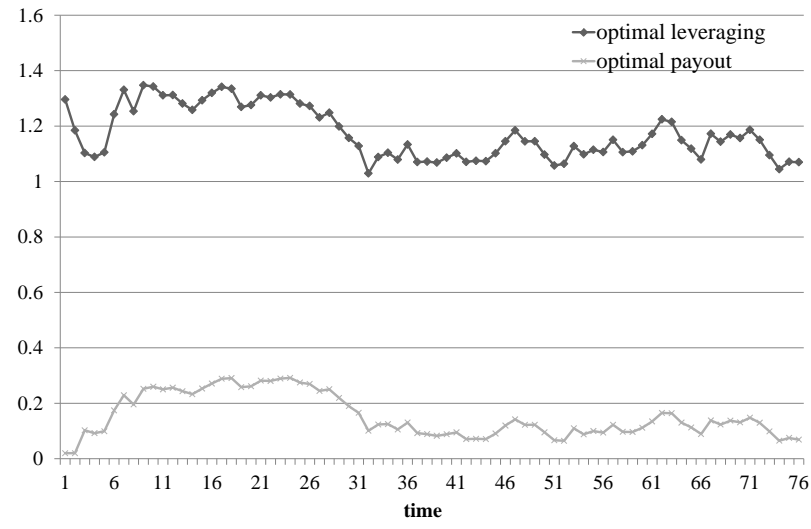

Figure 1: Path of optimal payout $c$ (light grey line) and optimal leveraging, $x=(1+f)$ (grey line)

\footnotetext{
${ }^{14}$ Stein (2012) postulates that the interest rate shocks are highly negatively correlated with capital gains' shocks, we have thus a negative sign for the stochastic term in equ. (2) after the interest rate. We also assume that the interest rate shocks have a smaller variance than the capital gains' shocks. But of course, if the perception arises that there is a default risk of certain banks, risk premia on banks' borrowing will suddenly increase. Both will drive down net worth of banks further, possibly creating a credit related systemic banking crisis.
} 
In Figure 2 the black line is the path of net worth and the red line is the process of stochastic shocks, giving rise to the volatility of the payout and leveraging in Figure 1. Note that the actual leveraging could be driven by other forces as well (see Sect. 3) and thus actual leverage can move in a different direction than the optimal leverage.

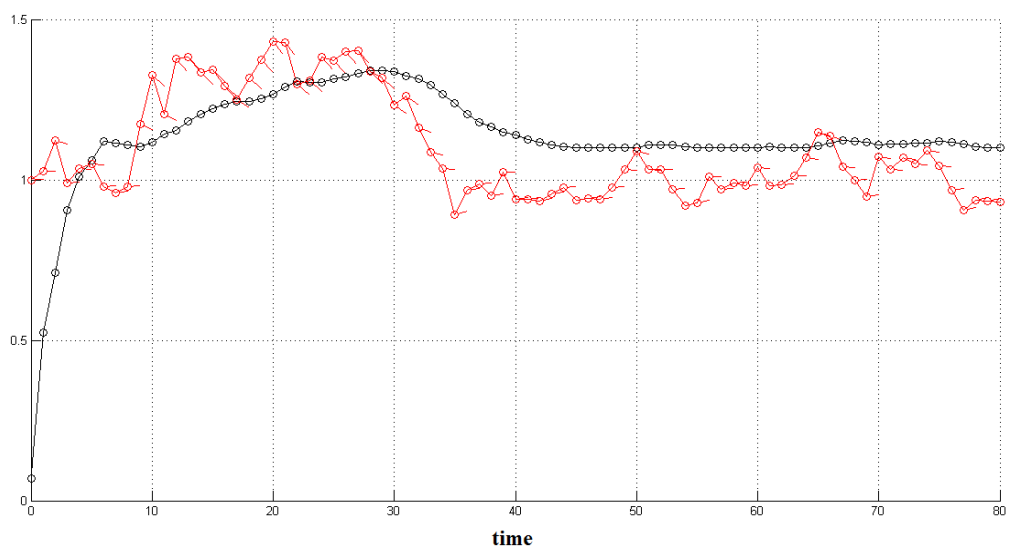

Figure 2: Paths of net worth $\left(x_{1, t}\right)$, modeled by equ. (2) (black line); stochastic process, modeled by (3) (red line) with initial net worth condition below the stochastic steady state

One should also point out that as the leveraging goes up (see the period from 1 to 25) the payout and net worth go up. Leveraging, however, could be restricted. This is what regulatory policy would like to engineer. It can be achieved if leveraging restrictions are imposed. ${ }^{15}$ On the other hand, with no leverage restrictions, leverage and payouts are rising (see the period after iteration 25 in Figure 1). The rising leverage could lead to the default of a bank or, through contagion effects, of many banks, a process central in Brunnermeier and Sannikov (2014).

Yet, in the current set up we have not modeled default probabilities and default intensities. They depend not only on the overleveraging of banks but also on liquidity ratios of banks and macro feedback effects. Moreover, the model above so far tracks only optimal leveraging, not the actual or excess leveraging. The Stein (2012) model can neatly make the distinction between optimal debt, actual debt and excess debt. It does not specify the more precise macro feedback mechanisms that build up excess debt.

The Brunnermeier and Sannikov (2014) model does this only in a very stylized way through the fire sale of assets and volatility jumps. To explain such excess debt dynamics in its feedback to the macroeconomy, recent finance-macro models employed by De Grauwe and Macchiarelli (2013) and Schleer and Semmler (2013) might be helpful.

The mechanism of debt build up that De Grauwe and Macchiarelli (2013) offer is that with rising prices of the borrowers' assets (firms, households) and their capital gains, they become more creditworthy, so that banks are going into the "risk taking channel", accepting lower credit spread and lending more, but exposing themselves to a greater extent to the borrower. However, as aggregate demand rises and the economy expands, this creates more cash flows and higher equity prices, higher net worth and so on, until

\footnotetext{
${ }^{15}$ In the context of our model and our solution method this can be easily done, as in Christiano and Ikeda (2013), by imposing leverage restrictions on $x_{t}$.
} 
the process reverses. For more details of the dynamics of the macro-finance link driving credit expansions and contractions, see De Grauwe and Macchiarelli (2013), Gerali et al. (2010), and Schleer and Semmler (2013).

\section{Overleveraging in the European banking sector}

Next, we describe the theoretical derivation of optimal debt and discuss the calculation and data issues of optimal and actual debt. Then, we present results on actual as well as optimal debt, our measure of overleveraging, and its evolution over time for the European banking sector. Besides the derivation of debt for individual banks, we also compute country-specific and country-group-specific aggregates based on the respective banks for each country or group.

\subsection{Calculation of optimal and actual debt}

Let us now measure optimal debt based on the model of Stein (2012) and contrast it to actual debt of 40 large European banks from 1997 to 2012. The difference between actual and optimal debt yields a measure for overleveraging or excess debt for each individual bank.

\section{Optimal debt ratio:}

One way to obtain the optimal debt ratio is through the dynamic solution of equations (1)-(3) of Section 2. The measure of optimal debt can, however, also analytically be obtained from a model of return-risk trade-off by maximizing the difference between the return and the risk term (see Stein 2012, Ch.4.9 and Appendix B). Roughly speaking, the optimal debt ratio is positive only if the return including capital gains exceeds the risk premium and the interest rate. The optimal debt ratio is not a constant, but rather varies directly with the return, the interest rate, and a measure of risk. An important driving force of the optimal debt ratio is the stochastic process representing the capital gains and interest rates.

Stein (2012) shows how the optimal debt ratio can directly be derived in the simplified case of logarithmic utility. ${ }^{16}$ The objective function hereby is log utility of consumption over a finite horizon and the state variable is a stochastic differential equation for net worth as defined in equation (4).

$$
d X(t)=X(t)[(1+f(t))(d P(t) / P(t)+\beta(t) d t)-i(t) f(t)-c d t],
$$

where $X(t)$ is net worth ${ }^{17}, f(t) \equiv L(t) / X(t)$ debt over net worth; thus leverage, $d P(t) / P(t)$ denotes stochastic capital gains or losses, and $i(t)$ the interest rate, also stochastic. Assets over net worth are defined as $(1+f(t)), \beta(t)$ is trend productivity of capital, and $C(t) / X(t) \equiv c(t)$ is consumption over net worth, in the derivation, $c$ is taken as given.

The optimal debt ratio $f^{*}$ maximizes the difference between the mean $M(f(t))$ and risk

\footnotetext{
${ }^{16}$ For a complete description of the derivation relying on Model I of Stein (2012) see Appendix B.

${ }^{17}$ Since we have here only one state variable, we are using $X(t)$ now as net worth.
} 
$R(f(t))$ which represents a mean-variance formulation. So we have:

$$
f^{*}=\operatorname{argmax}[M(f(t))-R(f(t))]=\left[(a(t)+\beta(t)-i)-\left(\sigma_{p}^{2}-\rho \sigma_{i} \sigma_{b}\right)\right] / \sigma^{2},
$$

where $\sigma$ is a risk element given by $\sigma^{2}=\sigma_{i}^{2}+\sigma_{r}^{2}-2 \rho \sigma_{i} \sigma_{r}$, and $\sigma_{i}^{2}$ is the variance of the interest rate, $\sigma_{r}^{2}$ is the variance of capital gains, and $\rho$ defines the correlation of $i$ and $r$. In this model variant Stein (2012) assumes that the asset price grows at a trend rate and there is a deviation from the trend, see equation (6) and for more details Appendix B.

$$
d P(t) / P(t)=(r+\alpha(0-y)) d t+\sigma_{r} d w_{p}
$$

Moreover, $\beta(t)$ is considered as deterministic. The optimal debt or leverage ratio $f^{*}(t)$ is defined as follows

$$
f^{*}(t)=\left[(r-i)+\beta-\alpha y(t)-\frac{1}{2} \sigma_{r}^{2}+\rho \sigma_{i} \sigma_{r}\right] / \sigma^{2},
$$

where $r$ denotes capital gains, $i$ the credit cost of banks, $\beta$ the trend productivity of capital, and $y(t)$ is the deviation of capital gains from its trend. Then follows the variance term with the parameters as described above.

Given those measures, one can employ data to derive the optimal debt ratio for the EU banks of interest. We now give a detailed explanation of the empirical calculation of the optimal debt ratio, the data used, and discuss conceptional issues. We rely on annual data as some measures are only available as annual observation (year-end-data). Data is obtained from Thomson-Reuters-Datastream. Capital gains are calculated as quarterly growth rates of the stock market capitalization (market cap) of the bank. The market cap data is given quarterly and computed as the product of the stock market price and the common shares outstanding. The common shares outstanding are the difference between issued shares and treasury shares. The market cap is subject to stock market swings. To eliminate these, and to obtain a smoothed series of capital gains as expected value of capital gains, a MA(11) is applied to obtain $r$. By using a MA(11), we include the previous/next year as well as one month from the year before/after to mitigate exceptional events occurring just within one year. Thus, we account for price deviations $y(t)$ from the trend as modeled in Stein (2012), see equation (6).

For $i$ we take the 1-year interbank rate for the home country of each bank. The rate most likely reflects best the credit costs of banks. The productivity of capital $\beta$ is calculated by dividing the bank's gross income (revenues minus salary) by the banks' assets for each period. ${ }^{18}$ Then, we compute the trend of $\beta$ (mean over the period 1997-2012). We also

\footnotetext{
${ }^{18}$ More precisely, net sales or revenues represent gross sales and other operating revenue less discounts, returns and allowances. They include but are not restricted to: Interest and fees on loans, Interest on Federal Funds, Interest on Bank Deposits, Interest on State, County and Municipality Funds, Interest on U.S. Government and Federal Agencies Securities, Federal Funds sold and securities purchased under resale agreements, Lease Financing, Net leasing revenue, Income from Trading Accounts, Foreign Exchange Income, Investment Securities gains/losses, Service Charges on Deposits, Other Service Fees, Trust Income, Commissions and Fees. Salaries and benefits expenses represent wages paid to employees and officers of the bank. They include but are not restricted to: All employee benefits such as health insurance and contributions to pension plans.
} 
calculate the correlation $\rho$ of the capital gains $r$ and the interest rate $i$ over the entire period. This is then used as a constant value over the period. Similarly, the standard deviations and variance of the interest rate and capital gains are also constant.

The risk element $\sigma$ is given as the sum of the variances $\sigma_{i}^{2}$ and $\sigma_{r}^{2}$ deducting twice the product of the standard deviation of the interest rate, the standard deviation of capital gains, and the correlation between them. The optimal debt ratio is then normalized by calculating the difference between the optimal debt ratio and the mean over the period and dividing it by the standard deviation.

\section{Actual debt ratio:}

The actual debt ratio is calculated as the amount of long-term debt over total assets. ${ }^{19}$ Again, the actual debt ratio is normalized to match its unit to the one of the optimal debt ratio.

\subsection{Results}

Following the above measure, we calculate optimal and actual debt for 40 European banks, representing the group of the largest banks of 17 countries in Europe. ${ }^{20}$

In the following, we present results of country groups. There is quite a heterogeneity to be found across Europe and banks in some EU regions tend to be more fragile than others. The groups of countries are Europe (EUR), EU, euro area (EA), euro area north (EA-n), euro area south (EA-s), and the crisis countries (PIIGS), presented in Table $1 .{ }^{21}$ The aggregates consist of banks belonging to the respective country group. Thereby, each bank is weighted by its market capitalization with respect to the individual aggregate to obtain a representative measure. In Appendix $\mathrm{C}$ the detailed results for each large bank in Europe is reported.

TABLE 1: Country groups

\begin{tabular}{l|l}
\hline \hline Europe (EUR) & AUT, BEL, DEN, FIN, FRA, GER, GRE, IRE, ITA, NLD, NOR, POL, PRT, ESP, SWE, CH, UK \\
EU & $=$ EUR without CH and NOR \\
Euro area (EA) & $=$ EU without DEN, POL, SWE, UK \\
EA north (EA-n) & AUT, BEL, FIN, FRA, GER, NLD \\
EA south (EA-s) & ESP, GRE, PRT, ITA \\
PIIGS & $=$ EA-s and IRE \\
\hline
\end{tabular}

To begin with, the overall picture is unambiguous. Before the year 2004 overleveraging has not been a serious problem and leveraging was on a sustainable level for most areas (see Figure 3). However, in the run-up to the financial crisis actual and optimal debt

\footnotetext{
${ }^{19}$ Long-term debt includes all interest bearing financial obligations, excluding amounts due within one year. Assets represent the sum of cash and due from banks, total investments, net loans, customer liability on acceptances (if included in total assets), investment in unconsolidated subsidiaries, real estate assets, net property, plant and equipment and other assets. Note that we do not use quarterly averages but year-end stock values. Long-term debt is not available at quarterly frequency for all banks over the complete time period. To ensure comparability across banks and over time, we stick to annual data.

${ }^{20}$ The countries include Austria, Belgium, Denmark, Finland, France, Germany, Greece, Ireland, Italy, Netherlands, Norway, Poland, Portugal, Spain, Sweden, Switzerland, and United Kingdom. The banks considered are listed in the Appendix C.

${ }^{21}$ The groups consist of countries belonging to the EUR, EU, etc., but do not necessarily comprise all countries belonging to the group.
} 
increasingly diverged and the banking sector began to suffer from overleveraging (see Figures 3 and 5). This is particulary pronounced in the periphery countries of the euro area. It can be considered as a period where the excess debt build up can be interpreted as an early warning mechanism. ${ }^{22}$

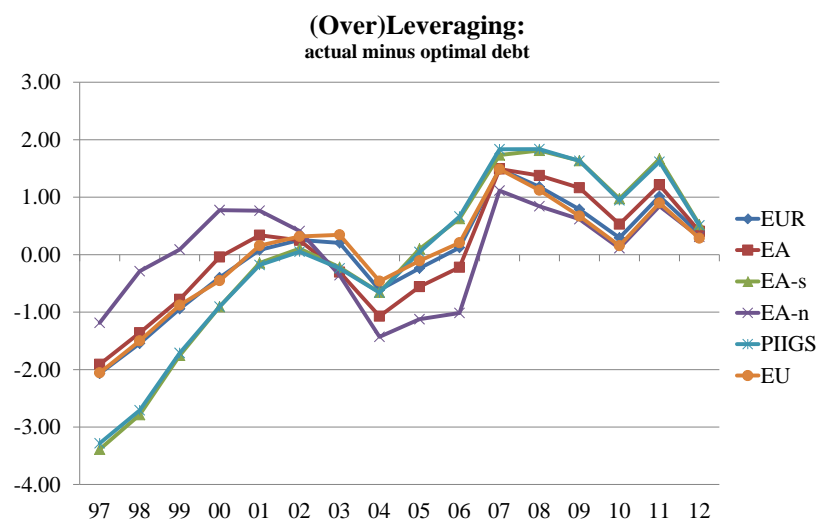

Figure 3: Deviation of actual from optimal debt - excess debt - in the banking sector, country groups

Recently, the difference between actual and optimal debt approaches zero and debt in the banking sector in the southern part of the euro area appears to converge toward a healthier level (see Figure 4). Yet, by our measure of overleveraging there is still a significant amount of vulnerability and fragility for some country groups and specific banks in certain countries.
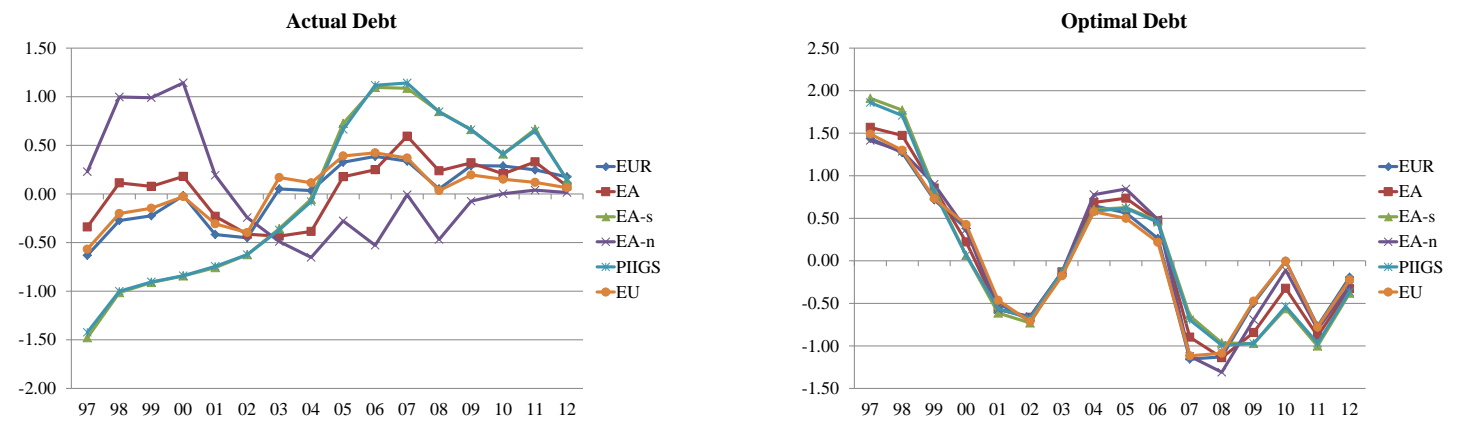

Figure 4: Actual and optimal debt in the banking sector, country groups

In Figure 3, it can also be seen that banks in EA-n left the path of optimal leveraging and became slightly overleveraged around the period of the dot-com bubble. However, the comparatively high actual debt level was reduced to a sustainable degree around 2003.

\footnotetext{
${ }^{22}$ Alessi and Detken (2014) have used other indicators as early warning signs for the period before 2007-08.
} 
From 2002 to 2005 the country groups considered featured a reasonable and healthy degree of leverage such that actual debt is always close to, but never exceeds optimal debt. This, however, reverses about the years 2005 and 2006. Banks in PIIGS and EA-s countries start accumulating debt such that in those countries banks became overleveraged already in 2005-long before the Lehman collapse. For this time period, it can be seen from Figure 5 that optimal debt clearly decreased which led to a widening gap in the years 2006-2008, indicating larger overleveraging.
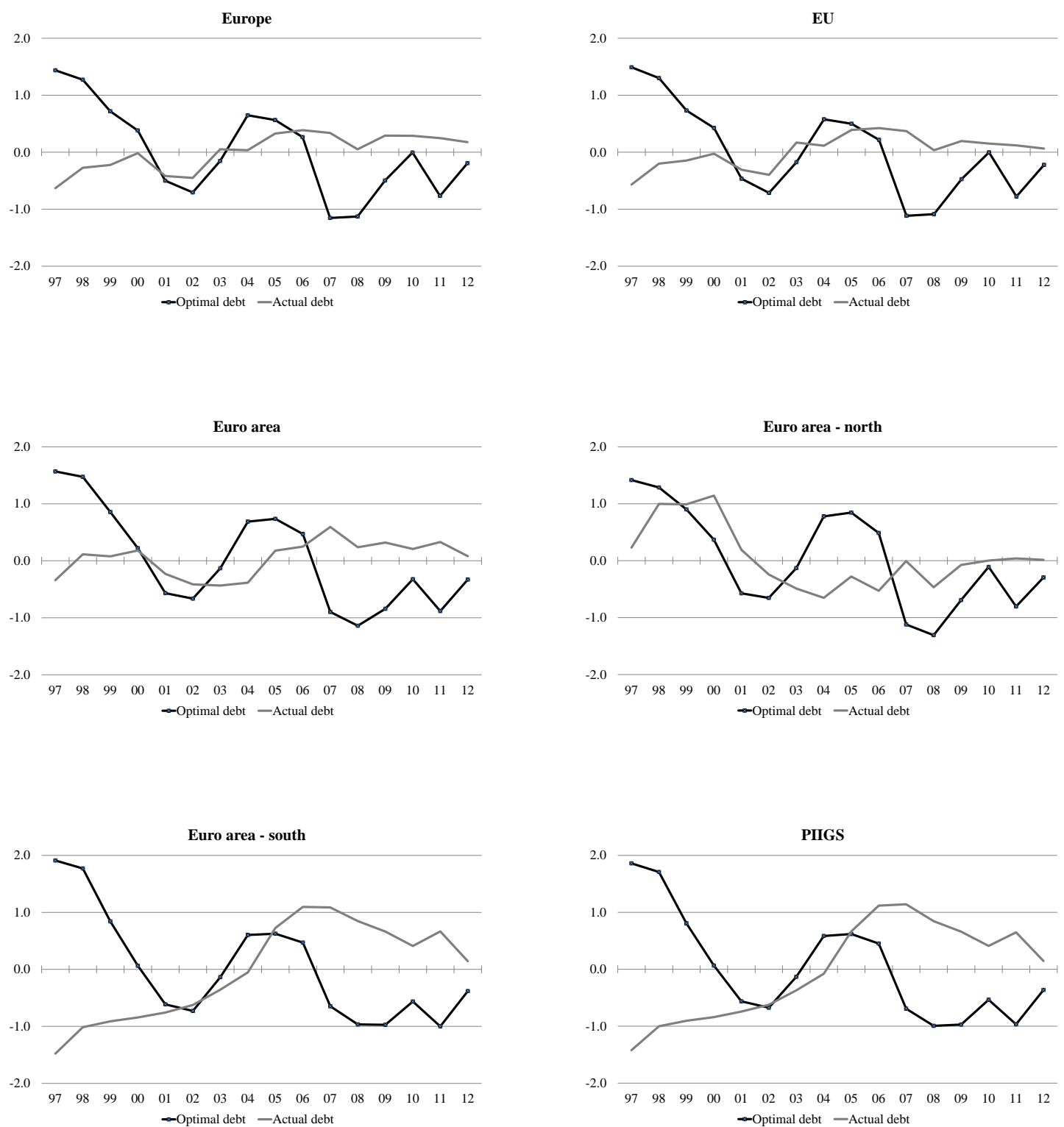

Figure 5: Actual vs. Optimal Debt, country groups

For this period, banks in EUR, EU, EA, and the EA-n started to be overleveraged as well. In contrast to the EA-s and PIIGS, this is primarily due to a decrease of optimal debt, whereas (normalized) actual debt increased only slightly. However, the banks in those 
areas did not manage to lower their actual debt level to reach or converge to the optimal one, but rather remained overleveraged for a while, though the degree of excess debt was lower than in EA-s and PIIGS.

In 2010, overleveraging was eased, yet still the EA-s and PIIGS remainded at the upper end and EA-n at the lower bound. Then, however, the sovereign debt crisis set in heavily and actual and optimal debt started to diverge again, with a particularly sharp increase for the banks in the periphery countries of the euro area. Interestingly, for those countries both actual and optimal debt ratio expanded in the wrong direction, whereas actual debt of the banks in the other country groups on average remained identically.

Note, however, that one should always focus on the difference between actual and optimal debt, which is our measure of interest. Overleveraging was and still tends to be more severe in banks in EA-s and PIIGS. Both country groups show approximately the same degree of excess debt. This convergence was likely to be driven by both financial aid and bailout programs for distressed or insolvent banks. In 2012, the actual debt approaches optimal debt for all country groups.

\section{Empirical analysis based on a non-linear Vector STAR model}

Next, we present some descriptive statistics and stylized facts between overleveraging in the banking sector, credit provision to the private sector, and economic activity. Then, we study the relationship by using a Vector STAR (VSTAR) model.

\subsection{Descriptives}

The virtue of having now time series data on excess leveraging of individual banks is that we are now able to analyze the link between credit, GDP growth and overleveraging in the banking sector in European country groups. The motivation of our study in this section comes from the considerations of Admati and Hellwig (2013) who point out detrimental effects to credit and output when a certain threshold of the leverage ratio is reached. This indicates that a banking sector, suffering from overleveraging, constrains credit flows and makes the real sector more vulnerable. Admati and Hellwig (2013) put forward this general hypothesis but do not test their view empirically. Yet, this hypothesis relates well to our measure of overleveraging and motivates our empirical non-linear analysis.

We therefore use a non-linear VSTAR model to study the link between credit and GDP in economies based on an exogenous regime-determining variable, namely overleveraging, which is the deviation of actual from optimal debt in the banking sector. Thus, we are able to distinguish between credit and output effects when either banks in an economy tend to be overleveraged or when banks tend to converge toward sustainable debt levels and constrain credit less. Based on our theoretical considerations and the experiences of the financial and economic crises, we would expect that overleveraging in the banking sector makes the economy more vulnerable to shocks and, thus, entailing a credit and 
output contraction. ${ }^{23}$

In general, there seems to be a significant positive correlation between bank lending to the private sector, namely credit growth, and GDP growth. It is well recognized that a lower credit growth goes hand in glove with lower GDP growth (Alessi and Detken 2014). This also holds for all our country groups, see Table 2. The correlation is lowest - but still positive - for the northern countries. It is more pronounced, however, for the periphery countries of the euro area, see the EA-s and PIIGS.

TABLE 2: Correlation between credit, GDP growth and the measure of (over-)leveraging in the banking sector, country groups

\begin{tabular}{l|cccccc}
\hline \hline & EUR & EU & EA & EA-n & EA-s & PIIGS \\
\hline GDP / credit & $\mathbf{0 . 5 5}$ & $\mathbf{0 . 5 6}$ & $\mathbf{0 . 4 7}$ & $\mathbf{0 . 3 7}$ & $\mathbf{0 . 5 1}$ & $\mathbf{0 . 5 2}$ \\
GDP / leveraging & $-\mathbf{0 . 3 8}$ & $-\mathbf{0 . 3 6}$ & $-\mathbf{0 . 4 0}$ & -0.21 & $-\mathbf{0 . 4 8}$ & $-\mathbf{0 . 5 0}$ \\
credit / leveraging & $-\mathbf{0 . 3 7}$ & $-\mathbf{0 . 3 5}$ & $-\mathbf{0 . 3 3}$ & -0.11 & -0.18 & -0.20 \\
\hline 2012Q4, quarterly data. & Bold & numbers & indicate significance at the $5 \%$-level. The
\end{tabular}

1998Q1-2012Q4, quarterly data. Bold numbers indicate significance at the 5\%-level. The

higher leveraging (excess debt), the higher banks' leverage ratio (actual minus optimal debt).

EUR: Europe; EU: European Union; EA: euro area; EA-n: euro area north; EA-s: euro area

south; PIIGS: crisis countries.

The higher correlation in the southern European countries is also likely to be a result of the debt crisis in these countries. The credit crunch, triggering adverse effects in the real economy, has been particularly severe and persistent for the southern part of the euro area and the crisis countries (PIIGS), respectively.

The positive correlation between credit and GDP growth also holds for most of the individual countries except Norway and Switzerland, see Table 3. The correlation is highest for Spain, and also comparatively high for the other crisis countries. The correlation between GDP and credit in Germany is, for instance, not pronounced for the time period under study.

TABLE 3: Correlation between credit, GDP growth and the measure of (over-)leveraging in the banking sector, individual countries

\begin{tabular}{l|ccccccccc}
\hline \hline & BEL & GER & AUT & FIN & FRA & GRE & IRE & ITA & NLD \\
\hline GDP / credit & $\mathbf{0 . 4 9}$ & 0.03 & $\mathbf{0 . 2 8}$ & 0.11 & $\mathbf{0 . 3 7}$ & $\mathbf{0 . 2 6}$ & 0.22 & 0.23 & $\mathbf{0 . 4 6}$ \\
GDP / leveraging & -0.12 & -0.15 & -0.06 & $\mathbf{- 0 . 3 6}$ & $\mathbf{- 0 . 3 2}$ & -0.15 & $\mathbf{- 0 . 2 7}$ & $\mathbf{- 0 . 4 2}$ & -0.01 \\
credit / leveraging & -0.03 & -0.11 & -0.10 & -0.14 & -0.09 & -0.17 & 0.03 & -0.13 & 0.16 \\
\hline & PRT & ESP & CH & UK & POL & SWE & DEN & NOR & \\
\hline GDP / credit & $\mathbf{0 . 3 7}$ & $\mathbf{0 . 7 2}$ & -0.25 & $\mathbf{0 . 4 2}$ & 0.23 & $\mathbf{0 . 3 9}$ & 0.21 & -0.05 & \\
GDP / leveraging & $\mathbf{- 0 . 4 7}$ & $\mathbf{- 0 . 4 8}$ & -0.14 & -0.05 & $\mathbf{0 . 3 7}$ & -0.25 & -0.22 & -0.16 & \\
credit / leveraging & $\mathbf{- 0 . 4 3}$ & -0.18 & $\mathbf{0 . 3 3}$ & -0.15 & $\mathbf{0 . 3 4}$ & -0.03 & 0.06 & 0.23 & \\
\hline
\end{tabular}

1998Q1-2012Q4, quarterly data. The higher leveraging (excess debt), the higher banks' leverage ratio (actual minus optimal debt). Bold numbers indicate significance at the 5\%-level.

Focusing on the averages of credit and GDP over the period guides us to another interesting aspect. In Figure 6, the average GDP and credit growth from 1998-2012 for all countries is depicted. PIIGS, in particular Greece and Portugal, show on average a rather high credit growth compared to GDP growth. Besides a fairly high positive correlation

\footnotetext{
${ }^{23}$ Though the overleveraging of the banking sector can be viewed as the primary mechanism of credit constrains the entailed rise of risk premia of banks, and increase of borrowing costs is presumably amplifying that mechanism.
} 
between GDP and credit growth, which might be driven by the reduction in both variables during or in the aftermath of the crisis, high credit growth seems to be accompanied by lower GDP growth on average over the whole time period, especially in the countries which suffered most from the financial and debt crisis.

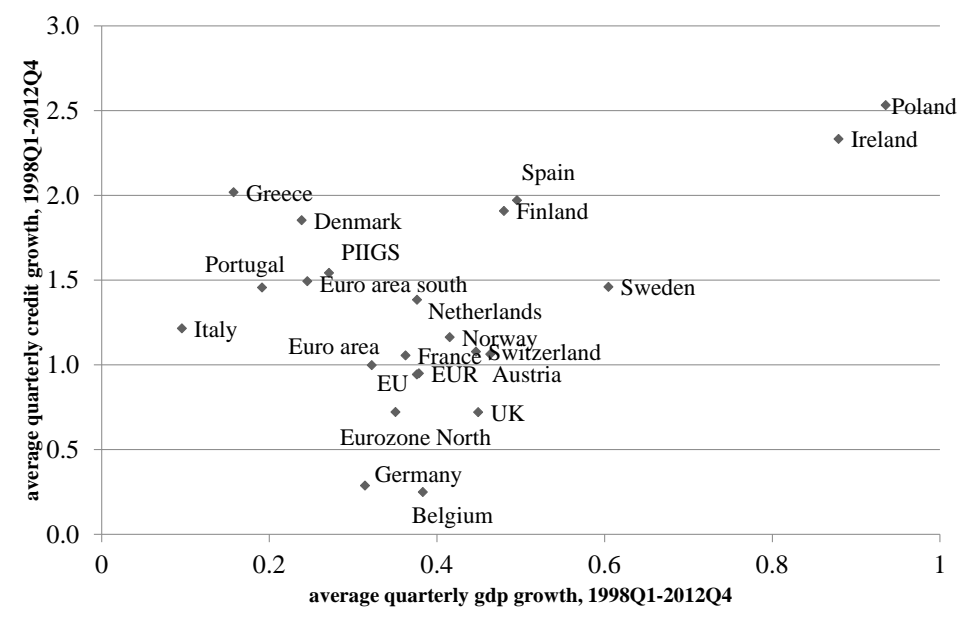

FIGURE 6: Average quarterly GDP and credit growth, 1998q1-2012q1

Having found a correlation between credit and GDP, we want to explore their relation to overleveraging in the banking sector. Since quarterly data for a number of banks is lacking, we use annual data for measuring overleveraging. Next, we convert annual frequency of the leverage measure to quarterly frequency by means of the quadratic match average method, so that we have all time series data at quarterly frequency. Our suggested method fits a quadratic polynomial to the series such that the average of the annual and quarterly series coincide. Later on, we use this series for the VSTAR analysis. This way we have - for all time series data - a sufficient number of observations for the models to be estimated.

In general, there is a negative correlation between excess debt (overleveraging in the banking sector) and GDP growth as well as growth of bank lending to the private sector. This can be observed in Tables 2 and 3. It indicates that the higher the debt in the banking sector is, the lower are GDP and credit growth in the countries or country groups under study (or vice versa).

Note that the negative correlation of the leverage ratio and GDP growth is by far highest and significant in EA-s and the PIIGS countries. ${ }^{24}$ The countries from the northern part of the euro area (EA-n) do not exhibit a significant correlation between GDP and leverage.

There is also a negative link between credit growth and overleveraging which is significant for Europe, the EU, and the EA. Banks that tend to be overleveraged may constrain lending. However, before the crisis there were times of overleveraged banks providing

\footnotetext{
${ }^{24}$ Note also that excess leveraging is driven by both actual and optimal leveraging. Thus, a jump in credit costs for refinancing, see the interbank rate spread in Appendix C, in a crisis regime may increase overleveraging in a period when output falls.
} 
credit in an unhealthy and excessive way to some sectors. This may explain the negative, but sometimes insignificant, correlation for most countries in our sample. Yet, a very clear link can be found for Ireland, Italy, Spain, and Portugal, which might be particularly driven by credit crunch.

Overall, there seems to be a relevant relation between overleveraging in the banking sector, bank lending to the private sector and real GDP growth in European economies. This appears to be important for the countries which suffer most from the economic crisis and ran into a (sovereign and private) debt crisis. These descriptive statistics make it worthwhile to study the link in a more structural way based on a non-linear Vector STAR model. The VSTAR model is able to distinguish between periods of overleveraging and sustainable debt levels and the respective consequences for the real economy.

\subsection{The Vector STAR model}

The VSTAR model is able to distinguish between regimes and to capture different dynamic properties across regimes. Overleveraging in the banking sector may lead to a contraction of bank lending, serious contagion effects, adverse feedback loops between the financial and the real sector, and slow recovery due to decreased credit flows. Hence, we define two regimes based on our measure for debt in the banking sector: (i) when the banking system tends to suffer from excess debt (overleveraging), and (ii) when the debt level tends to converge to a sustainable level. We thus use an exogenous variable to estimate the threshold of regime changes and determine regime-specific dynamics in the creditoutput nexus.

In our application, we apply a two-regime bivariate logistic Vector STAR model which is governed by a single transition function. It is defined as follows:

$$
\mathbf{y}_{\mathbf{t}}=\boldsymbol{\Phi}^{\prime} \mathbf{z}_{\mathbf{t}}+\boldsymbol{\Psi}^{\prime} \mathbb{G}_{\mathbf{t}}(.) \mathbf{z}_{\mathbf{t}}+\varepsilon_{\mathbf{t}}
$$

where $\mathbf{y}_{\mathbf{t}}=\left\{G D P_{t}, c r_{t}\right\}$ is a $2 \times 1$ column vector, where quarterly GDP and credit growth are endogenous variables. $\mathbf{z}_{\mathbf{t}}=\left(1, \mathbf{y}_{\mathbf{t}-\mathbf{1}}^{\prime}, \ldots, \mathbf{y}_{\mathbf{t}-\mathbf{p}}^{\prime}\right)^{\prime}$ is a vector of endogenous variables and a constant. $\boldsymbol{\Phi}^{\prime}$ and $\boldsymbol{\Psi}^{\prime}$ are coefficient matrices of dimension $(p k+1) \times k$, where $k=2$. The error term $\varepsilon_{\mathbf{t}}$ is assumed to be white noise with variance-covariance matrix $\Omega$.

In our application, we model the special case where one transition function governs the whole Vector STAR system: $\mathbb{G}_{\mathbf{t}}()=.\mathbf{g}\left(s_{t} \mid \gamma, c\right) \mathbf{I}_{\mathbf{k}}$. The transition function is of logistic type and looks as follows:

$$
\mathbf{g}\left(s_{t} \mid \gamma, c\right)=\left[1+\exp \left(-\gamma\left(s_{t}-c\right)\right)\right]^{-1}, \gamma>0
$$

It is bounded between zero and one, is monotonically increasing in $s_{t}$, and depends on the transition speed $(\gamma)$, the threshold $(c)$ as well as the transition variable $\left(s_{t}\right)$. The transition variable is either contemporaneous or the lagged first difference of excess debt in the banking sector of the respective country or the country group. If $\gamma \rightarrow \infty$, the model converges to a threshold VAR model and if $\gamma$ approaches zero it collapses to a linear VAR model. The location parameter $c$ defines the threshold. We expect that a value around zero should be found by the optimization procedure as zero divides periods of increasing 
and decreasing overleveraging of banks. ${ }^{25}$

\subsection{Results}

In the following, we estimate country-group-specific bivariate Vector STAR models based on quarterly GDP and credit growth with changes in excess leveraging compared to the previous quarter as exogenous transition variable. Using the first difference emphasizes debt dynamics in the banking sector. ${ }^{26}$ The first regime includes debt changes toward an (even) healthier level, i.e. a reduction of overleveraging (debt) in the banking sector; the second regime captures increases in debt in the banking sector, i.e. a rise toward higher (actual - optimal) debt, either above the optimal level or at least closer to it. To derive structural responses, we use a Cholesky decomposition where credit growth reacts to GDP shocks within the same quarter and GDP growth responds sluggishly to credit shocks. Linearity tests point toward a non-linear model and support our expectation of regime-specific dynamics in the credit-output nexus, see Table 4.

TABLE 4: Linearity tests, Rao's test-statistic

\begin{tabular}{l|cccccc}
\hline \hline & EUR & EU & EA & EA-n & EA-s & PIIGS \\
\hline p-val. & 0.0621 & 0.0473 & 0.0230 & 0.0616 & 0.0003 & 0.0003 \\
lag of $s_{t}$ & 2 & 2 & 3 & 3 & 3 & 3
\end{tabular}

The linearity test is implemented following Teräsvirta and Yang (2014a).

Granger causality tests based on the estimated Vector STAR models indicate a significant interdependent GDP and credit growth relation for Europe, the EU, the EA, and the PIIGS countries. ${ }^{27}$ However, neither GDP nor credit growth seem to contain statistical relevant information for the future behavior of the other variable in the northern countries of the euro area. This questions the estimation of a bivariate Vector STAR model for EA-n. We will estimate the model nevertheless later on, but we should interpret the results with caution for that country group. Note also that credit does not seem to help forecasting GDP for EA-s, but GDP is statistically relevant for the future evolution of credit.

TABLE 5: Granger Causality, VSTAR model, Rao's test-statistic and p-values

\begin{tabular}{r|l|cccccc}
\hline \hline & & EUR & EU & EA & EA-n & EA-s & PIIGS \\
\hline \multirow{2}{*}{ credit $\rightarrow$ GDP } & test-stat. & 10.29 & 9.89 & 4.63 & 0.26 & 0.41 & 6.91 \\
& p-val. & 0.00 & 0.00 & 0.02 & 0.61 & 0.53 & 0.01 \\
\hline \multirow{2}{*}{ GDP $\rightarrow$ credit } & test-stat. & 13.17 & 12.31 & 9.23 & 1.70 & 14.38 & 7.76 \\
& p-val. & 0.00 & 0.00 & 0.00 & 0.20 & 0.00 & 0.01 \\
\hline & Estimation period of VSTAR & model, & $1998 Q 1-2012 Q 4 ;$ \\
& VS (Granger causes) $y$
\end{tabular}

In the following, we compute (non-linear) impulse response functions based on the method of Koop et al. (1996) that are able to capture regime-specific effects of shocks. Recent

\footnotetext{
${ }^{25}$ Similar and more detailed descriptions of Vector STAR models and their estimation can be found in Teräsvirta and Yang (2014b), Schleer (2013), and Schleer and Semmler (2013) for an application.

${ }^{26}$ Using the level of excess debt would imply to model basically a structural break for most countries about 1996. Moreover, the level might not be stationary for some country group.

${ }^{27}$ Estimates for $c$ and $\gamma$ can be found in the Appendix C in Table A.2.
} 
studies by Gilchrist and Mojon (2014), Bassett et al. (2014), Bijsterbosch and Falagiarda (2014), Avdjiev and Zeng (2014), Gilchrist and Zakrajšek (2012), Hristov et al. (2012), Serwa (2012), Helbling et al. (2011), de Bondt et al. (2010), Gilchrist et al. (2009), Alessandro and João (2006), and Balke (2000), to name a few, also analyze the link between credit dynamics and economic activity in one way or another. Connecting overleveraging of banks, bank lending to the private sector, and output dynamics in a regime change model is a novel feature of our study.
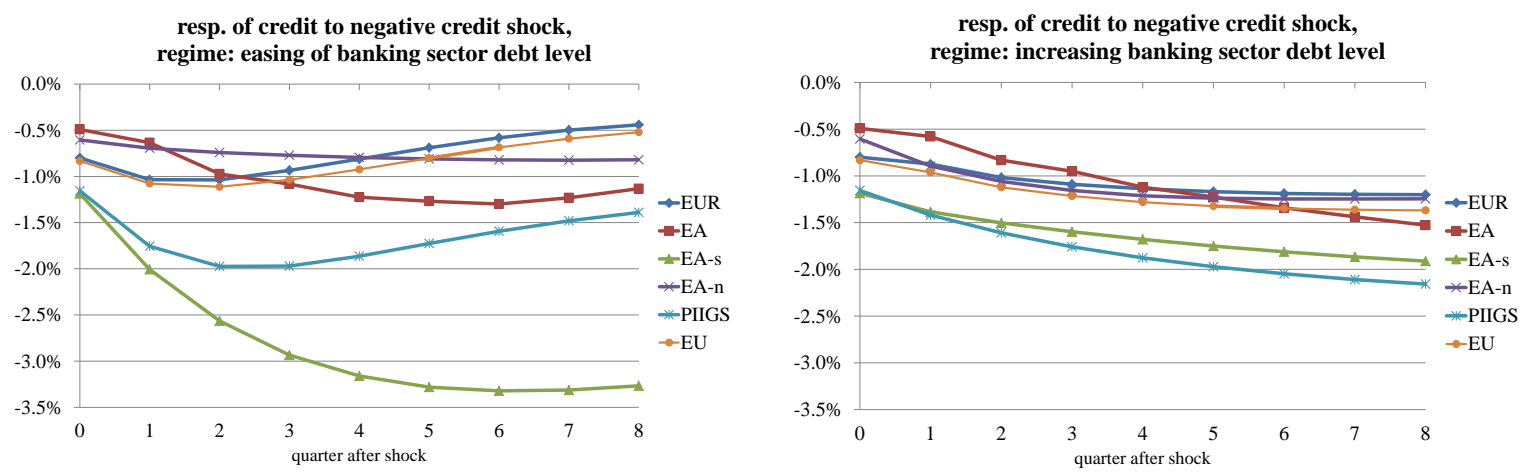

FIGURE 7: Response of credit to a negative 1 s.d. credit shock

After a negative one standard deviation shock to bank lending, we find asymmetric responses depending on the debt-regime of the banking sector, see Figure 7. The response of credit is - irrespective of the regime - negative, but more severe when the shock occurs during a period of increasing leveraging in the banking sector. The response is longlasting and persistently negative which is contrary to a regime of easing banking sector debt levels. The response of credit is initially negative but shows a slight upward trend three quarters after the shock. ${ }^{28}$
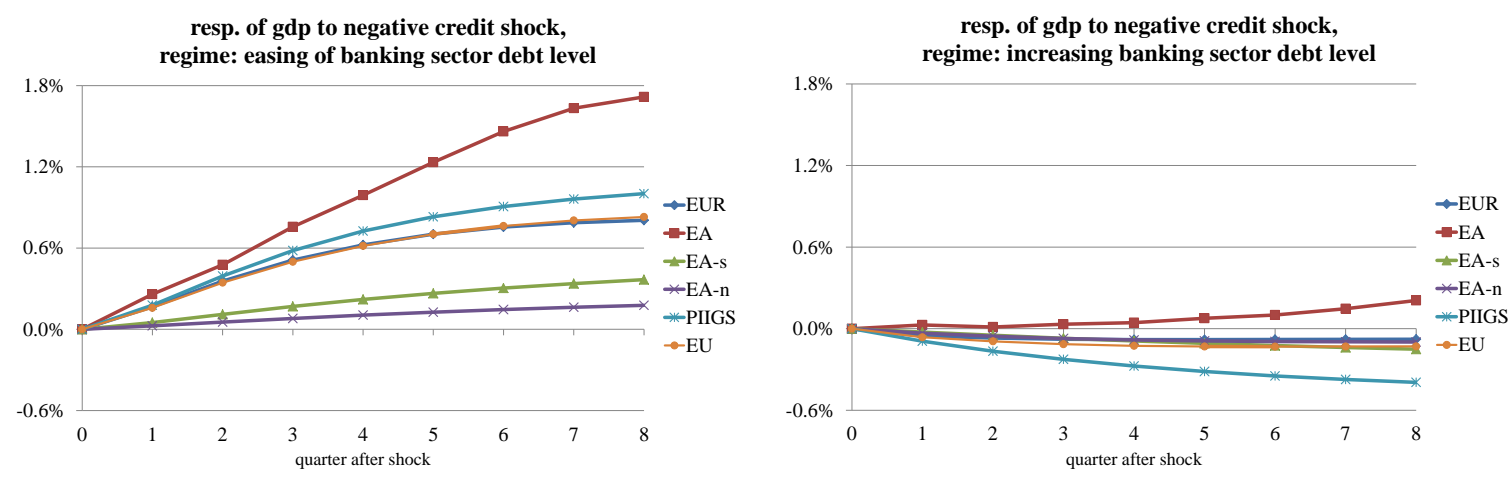

Figure 8: Response of GDP to a negative 1 s.d. credit shock

Thus, bank lending is able to recover when the debt level in the banking sector tends to be on a sustainable path. When the debt level moves away from being optimal, however, bank lending will be constrained greatly after a shock to lending. This holds particularly

\footnotetext{
${ }^{28}$ The euro area south shows a stronger credit contraction in a regime of relaxing debt levels. The IRFs, however, allow for regime-switching after the initial shock. Thus, an immediate switch to the excess-debt-regime might create this unexpected severe reduction.
} 
for the periphery countries of the euro area and the so-called crisis countries (PIIGS). For these countries, we find a $2 \%$ lower level of credit supply.
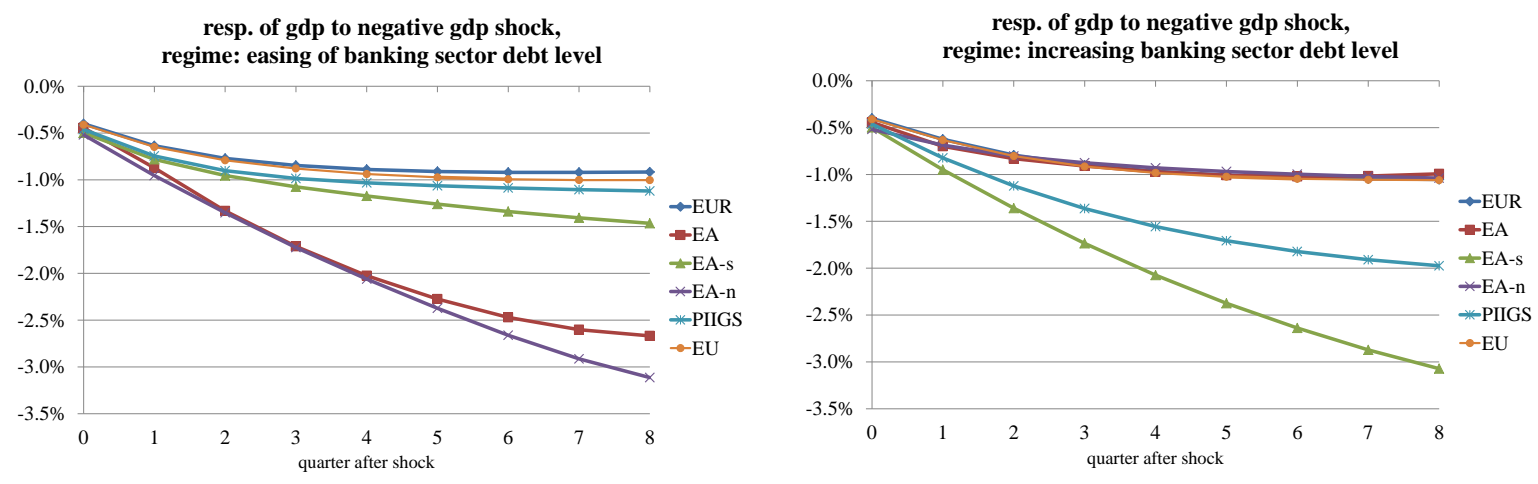

FigURE 9: Response of GDP to a negative 1 s.d. GDP shock

GDP also reacts in a non-linear way after a negative shock to credit, see Figure 8. Interestingly, we cannot detect a negative response of GDP in a regime of reasonable or decreasing debt levels. A negative credit shock does not appear to have negative output consequences after bank lending is constrained. In a regime of increasing debt levels of the banking sector, however, output will be adversely affected. Eight quarters after a shock to credit supply, GDP is clearly on a lower level than before. It is reduced by approximately $0.1 \%$ for Europe as well as the northern countries of the euro area. A credit shock, however, is more harmful for the EA-s as well as PIIGS, where GDP is around $0.2 \%-0.4 \%$ lower. This result is in line with recent experiences, as these countries also suffer to a greater extent from a credit crunch related to the financial and economic crisis, although the effects are not so strong in quantitative terms.
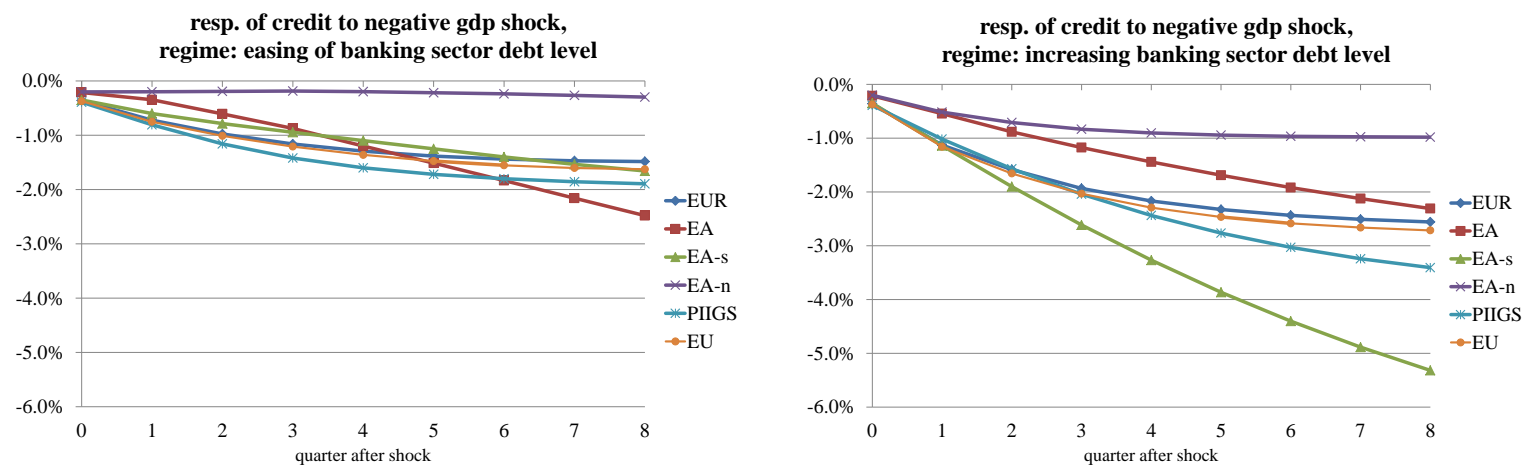

FiguRE 10: Response of credit to a negative 1 s.d. GDP shock

A negative shock to GDP has a negative impact on GDP and credit irrespective of the regime for all country groups. The magnitude of this effect, however, differs with respect to the regime and the country group. Output is specifically adversely affected again for the periphery countries of the euro area when there is overleveraging in the banking sector. For instance, a negative shock causes GDP to drop by more than 3\% for EA-s when overleveraging tends to pose a threat to the banking sector. ${ }^{29}$

\footnotetext{
${ }^{29} \mathrm{GDP}$ is surprisingly strongly reduced for the EA and the EA-n in a regime when there is an easing of the banking sector debt level. This may be due to significant spillover and contagion effects in Europe.
} 
Figure 10 shows that a negative GDP shock results in a severe credit crunch when the banking sector is overleveraged or has steadily increasing debt levels. Banks greatly constrain their lending to the private sector: by more than $5 \%$ in EA-s and 3\% in the crisis countries (PIIGS); EA, EUR, and EU by around $2 \%$, and in the EA-n only by $1 \%$. The shock is more severe in times of excess debt in the banking sector, as then a (credit) bubble may burst, and increasing credits spreads may lead to a deterioration in bank lending. Credit flows are constrained less in a regime when the leverage ratio moves in a healthier region. Except for the euro area, the adverse credit effect of a negative GDP shock diminishes after four quarters. 


\section{Conclusions}

Overleveraging of the banking sector exposes the financial sector and the macroeconomy to vulnerabilities but also, as critics state, seems to constrain credit flows to the private sector. We introduce a dynamic model on optimal or sustainable leveraging. We then present a measure of overleveraging defined as the difference of actual and sustainable debt. Furthermore, we conduct an empirical study on overleveraging for 40 banks in Europe, and study the vulnerabilities of banks, their risk premia, and credit and output contractions that can arise subsequently.

Before the period 2004 overleveraging does not seem to pose a serious problem and leveraging was on a sustainable path. However, in the run-up to the financial crisis actual and optimal debt diverged and the banking sector began to suffer from overleveraging. This can be interpreted as an early indicator of a coming vulnerability of banks, sudden rise in credit spreads, and a credit crisis.

We use a non-linear VSTAR model to evaluate the hypothesis that periods of high leveraging are accompanied by more severe credit and output contractions than periods of decreasing leveraging. We demonstrate this for country groups in Europe. Bank lending is able to recover after a shock to lending when the debt level in the banking sector tends to be on a sustainable path. When the debt level moves away from being optimal, however, bank lending will be constrained greatly. This holds particularly for the periphery countries of the euro area and the so-called crisis countries (PIIGS). GDP reacts also in a non-linear way after a negative shock to credit. In a regime of increasing debt levels of

the banking sector, output will be adversely affected. A credit shock, however, is more harmful for the EA-s as well as PIIGS.

Moreover, a negative output shock results in a severe credit crunch when the banking sector is overleveraged or has steadily increasing debt levels. Banks greatly constrain their lending to the private sector: by more than 5\% in EA-s and 3\% in the crisis countries (PIIGS); EA, EUR, and EU by around 2\%, and in the EA-n only by $1 \%$. The shock is more severe in times of excess debt in the banking sector, as then a (credit) bubble may burst, and increasing credits spreads may lead to a deterioration in bank lending.

Our analysis has implications for the new regulatory requirements set out by the BIS. Our study shows that one can largely agree with Admati and Hellwig (2013) that given the still overleveraged EU banking sector and the planned EU banking union higher capital requirements are essential to allow for the stability of the EU banking system and their provision of the credit flows for the public and private sector. In future work, it might be interesting to compare our methodology measuring overleveraging to the methodology used by the ECB in their recent stress-tests. 


\section{Appendix: Numerics, derivation of optimal debt, and additional results}

\section{A The numerical procedure}

For the numerical solution of our dynamic decision problem we employ a new procedure. ${ }^{30}$ Usually one uses DYNARE or Dynamic Programming (DP) to solve models such as presented in Section 2 (see Grüne and Semmler 2004). DYNARE undertakes some linearization and eliminates the non-linearities. The disadvantage of DP is that its numerical effort typically grows exponentially with the dimension of the state variable. Hence, even for moderate state dimensions it may be impossible to compute a solution with reasonable accuracy. A remedy to this problem can be obtained by using non-linear model predictive control (NMPC) (Grüne et al. 2013). Instead of computing the optimal value function for all possible initial states, NMPC only computes single trajectories.

In order to describe the method, let us abstractly write the dynamic decision problem as

$$
\text { maximize } \int_{0}^{T} e^{-\rho t} \ell(x(t), u(t)) d t,
$$

where $x(t)$ satisfies $\dot{x}(t)=f(x(t), u(t)), x(0)=x_{0}$ and the maximization takes place over a set of admissible decision functions. By discretizing this problem in time, we obtain an approximate discrete time problem of the form

$$
\operatorname{maximize} \sum_{i=0}^{T} \beta^{i} \ell\left(x_{i}, u_{i}\right) d t
$$

where the maximization is now performed over a sequence $u_{i}$ of decision values and the sequence $x_{i}$ satisfies $x_{i+1}=\Phi\left(h, x_{i}, u_{i}\right)$. Here $h>0$ is the discretization time step, $\beta=e^{-\rho h}$ and $\Phi$ is a numerical scheme approximating the solution of $\dot{x}(t)=f(x(t), u(t))$ on the time interval $[i h,(i+1) h]$. For details and references in which the error of this discretization is analyzed we refer to Grüne et al. (2013).

The idea of NMPC now lies in replacing the maximization of the above large horizon functional, where we could have $T \rightarrow \infty$, by the iterative maximization of finite horizon functionals

$$
\operatorname{maximize} \sum_{k=0}^{N} \beta^{i} \ell\left(x_{k, i}, u_{k, i}\right) d t
$$

for a truncated finite horizon $N \in \mathbb{N}$ with $x_{k+1, i}=\Phi\left(h, x_{k, i}, u_{k, i}\right)$ and the index $i$ indicates the number of the iteration, cf. the algorithm below. Note that neither $\beta$ nor $\ell$ nor $\Phi$ changes when passing from (A.2) to (A.3), only the horizon is truncated.

Problems of type (A.3) can be efficiently solved numerically by converting them into a static non-linear program and solving them by efficient NLP solvers, cf. Grüne and Pannek (2011). In our simulations, we use a discounted variant of the MATLAB routine which uses MATLAB's fmincon NLP solver in order to solve the resulting static optimization

\footnotetext{
${ }^{30}$ The description can also be found in Schleer and Semmler (2013) and Proano et al. (2014).
} 
problem.

Given an initial value $x_{0}$, an approximate solution of (A.2) can now be obtained by iteratively solving (A.3) as follows:

(1) for $\mathrm{i}=1,2,3, \ldots$

(2) solve (A.3) with initial value $x_{0, i}:=x_{i}$ and denote the resulting optimal control sequence by $u_{k, i}^{*}$

(3) $\quad$ set $u_{i}:=u_{0, i}^{*}$ and $x_{i+1}:=\Phi\left(h, x_{i}, u_{i}\right)$

(4) end of for-loop

This algorithm yields an infinite trajectory $x_{i}, i=1,2,3, \ldots$ whose control sequence $u_{i}$ consists of all the first elements $u_{0, i}^{*}$ of the decision sequences for the finite horizon subproblems (A.3).

Under appropriate assumptions on the problem, it can be shown that the solution $\left(x_{i}, u_{i}\right)$ (which depends on the choice of $N$ above) converges to the correct solution of (A.2) as $N \rightarrow \infty$. The main requirement in these assumptions is the existence of an equilibrium for the infinite horizon problem (A.2). If this equilibrium is known, it can be used as an additional constraint in (A.3), in order to improve the convergence properties. However, recent results have shown that without a priori knowledge of this equilibrium this convergence can also be ensured, see Grüne et al. (2013), and this is the approach we use in the computations in this paper. It should be noted that the references just cited treat averaged instead of discounted infinite horizon problems. However, Grüne and Pannek (2011) conjectures that the main arguments carry over to the discounted case details which will be addressed in future research. In any case, the solution generated by NMPC will always provide a lower bound for the true optimal solution.

\section{B Computation of the optimal debt}

Stein (2012, Ch.4.9) shows how the optimal debt ratio can be derived in the simplified case of logarithmic utility. The notation and description in this subsection is taken from Stein (2012, Ch.4.9, pp.71-73).

The stochastic differential equation for net worth is (A.4)

$$
d X(t)=X(t)[(1+f(t))(d P(t) / P(t)+\beta(t) d t)-i(t) f(t)-c d t]
$$

$X(t)$ denotes net worth, $f(t)=L(t) / X(t)$ debt over net worth, $d P(t) / P(t)=$ capital gain or loss, stochastic, $i(t)=$ interest rate, also stochastic, $(1+f(t))=$ assets over net worth, $\beta(t)=$ productivity of capital. ${ }^{31}$ Moreover, $c(t)=C(t) / X(t)$, consumption over net worth, where $c$ is fixed. Let the price evolve stochastically as

$$
d P(t)=P(t)\left(a(t) d t+\sigma_{p} d w_{p}\right)
$$

where Stein (2012) shows two different version-Model I or Model II - for the drift $a(t)$, which will be briefly explained below. The interest rate also evolves as a stochastic process.

\footnotetext{
${ }^{31}$ Subsequently, we will use a $\beta(t)$ that will represent trend productivity.
} 


$$
i(t)=i d t+\sigma_{i} d w_{i}
$$

Then, substitute (A.5) and (A.6) in (A.4) and derive (A.8)

$$
\begin{gathered}
d X(t)=X(t)[(1+f(t))(a(t) d t+\beta(t) d t)-(i f(t) d t+c d t)]+\left[(1+f(t)) \sigma_{p} d w_{p-} \sigma_{i} f(t) d w_{i}\right] \\
d X(t)=X(t) M((t) d t+X(t) B(f(t))
\end{gathered}
$$

The mean (A.9) and risk (A.12) term are defined as follows, where $B(t)$ in (A.10) contains stochastic variables (see also Stein (2012, Ch.4.5)):

$$
\begin{gathered}
\text { Mean }=M(f(t))=[(1+f(t)(a(t) d t+\beta(t)) d t-(i f(t)+c)] \\
B(t)=\left[(1+f(t)) \sigma_{p} d w_{p}-\sigma_{i} f(t) d w_{i}\right] \\
B^{2}(f(t))=\left(1+f(t)^{2} \sigma_{p}^{2} d t+f(t)^{2} \sigma_{i}^{2} d t-2 f(t)(1+f(t)) \sigma_{i} \sigma_{p} d w_{p} d w_{i}\right. \\
\text { Risk } \left.=R(f(t))=\left(\frac{1}{2}\right)\left[(1+f(t))^{2} \sigma_{b}^{2}+f(t)^{2} \sigma_{i}^{2}-2(t)(1+f(t)) \sigma_{b} \sigma_{i} \rho\right)\right]
\end{gathered}
$$

$M(f(t))$ contains the deterministic terms and $B(f(t))$ contains the stochastic terms. To solve for $X(t)$ consider the change in $\ln X(t)$, see (A.13). This is based upon the Ito equation of the stochastic calculus. As Stein (2012) shows using the logarithmic criterion implies that one does not need to use dynamic programming. The expectation of $d \ln X(t)$ is (A.14).

$$
\begin{gathered}
d \ln X(t)=(1 / X(t)) d X(t)-\left(1 / 2 X(t)^{2}\right)(d X(t))^{2} \\
E[d(\ln X(t))]=[M((t)]-R[((t)] d t]
\end{gathered}
$$

Equ. (A.14) represents a mean-variance formulation. The correlation $\rho d t=E\left(d w_{p} d w_{i}\right)$ is negative, which increases risk, where $(d t)^{2}=0, d w d t=0$.

The optimal debt ratio $f^{*}$ maximizes the difference between the mean and risk.

$$
\begin{gathered}
f^{*}=\operatorname{argmax}[M(f(t))-R(f(t))]=\left[(a(t)+\beta(t)-i)-\left(\sigma_{p}^{2}-\rho \sigma_{i} \sigma_{b}\right)\right] / \sigma^{2} \\
\sigma^{2}=\sigma_{i}^{2}+\sigma_{p}^{2}-2 \rho \sigma_{i} \sigma_{p}
\end{gathered}
$$

Model I assumes mean reversion so that the price $P(t)$ has a trend $r t$ and a deviation $y(t)$ 
from it (A.17). ${ }^{32}$ The deviation $y(t)$ for Model I follows an Ornstein-Uhlenbeck ergodic mean reverting process (A.18). Coefficient $\alpha$ is positive and finite.

$$
\begin{gathered}
P(t)=P(0) \exp [r t+y(t)] \\
d y(t)=-\alpha y(t)+\sigma_{p} d w_{p}
\end{gathered}
$$

Therefore using the stochastic calculus $a(t)$ in Model I is the first term in (A.19)

$$
d P(t) / P(t)=\left(r-\alpha y(t)+\left(\frac{1}{2} \sigma_{p}^{2}\right)\right) d t+\sigma_{p} d w_{p}
$$

Then, substitute (A.19) in (A.15) and derive (A.20), which is the optimal debt ratio in Model I.

$$
f^{*}(t)=\left[(r-i)+\beta-\alpha y(t)-\frac{1}{2} \sigma_{p}^{2}+\rho \sigma_{i} \sigma_{p}\right] / \sigma^{2}
$$

Hereby, $\beta(t)$ is considered as deterministic.

\footnotetext{
${ }^{32}$ Stein's second model variant (Model II) assumes a random walk for the capital gains with expected value of zero. In our empirical application for the specific (finite) sample, there may be capital gains which are on average slightly different from zero. Thus, Model I appears to be more reasonable.
} 


\section{Additional results and results of individual banks}

TABLE A.1: Correlation between group specific interbank rate spreads and the measure of (over-)leveraging in the banking sector

\begin{tabular}{cccccc}
\hline \hline EUR & EU & EA & EA-n & EA-s & PIIGS \\
\hline 0.5066 & 0.4484 & 0.5607 & 0.2407 & 0.7918 & 0.7808 \\
\hline
\end{tabular}
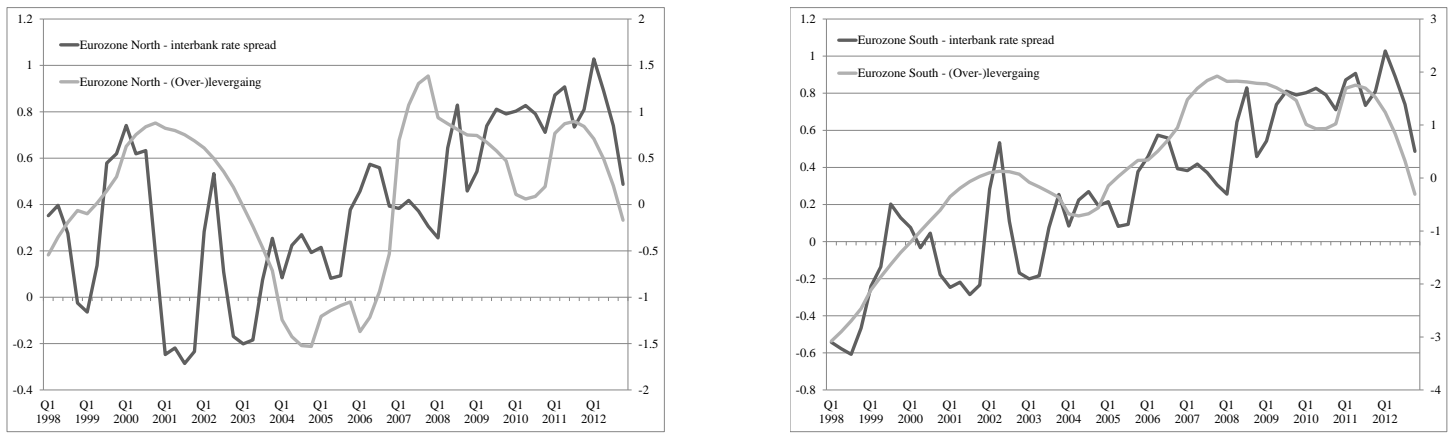

Interbank rate spreads: weighted average of country-specific interbank rate spreads (1-year rate minus 1-month rate), own calculations.

FIGURE A.1: Interbank rate spreads and the measure of (over-)leveraging in the banking sector, EA-n and ES-s

TABLE A.2: Estimates for $c$ and $\gamma$

\begin{tabular}{c|cccccc}
\hline \hline & EUR & EU & EA & EA-n & EA-s & PIIGS \\
\hline$c$ & 0.0299 & 0.0180 & -0.0797 & -0.0651 & -0.0008 & 0.0061 \\
$\gamma$ & 6.8431 & 5.1350 & 2.3336 & 1.7254 & 30.0000 & 30.0000 \\
\hline
\end{tabular}




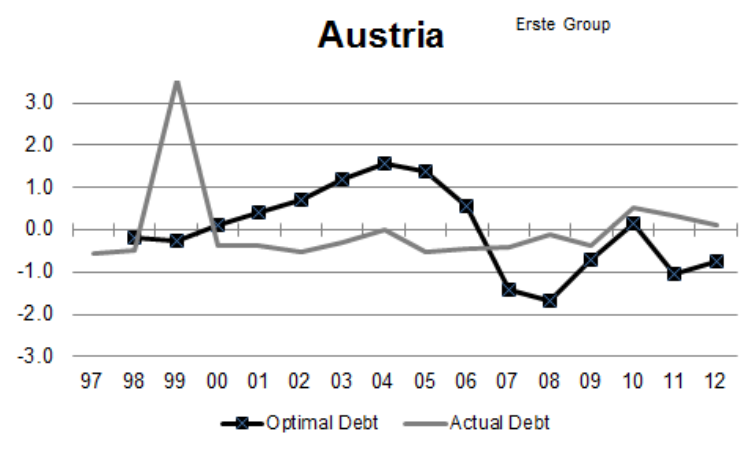

Denmark $\begin{gathered}\text { Danske Bank } \\ \text { Jyske Bank }\end{gathered}$

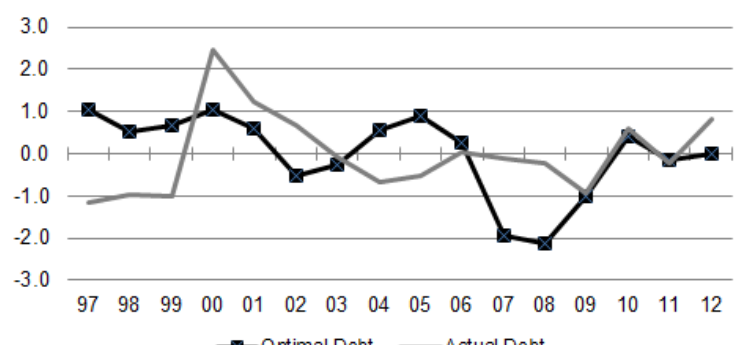

Belgium $\underset{\substack{\text { Dexia } \\ \mathrm{KBC}}}{\text { Den }}$

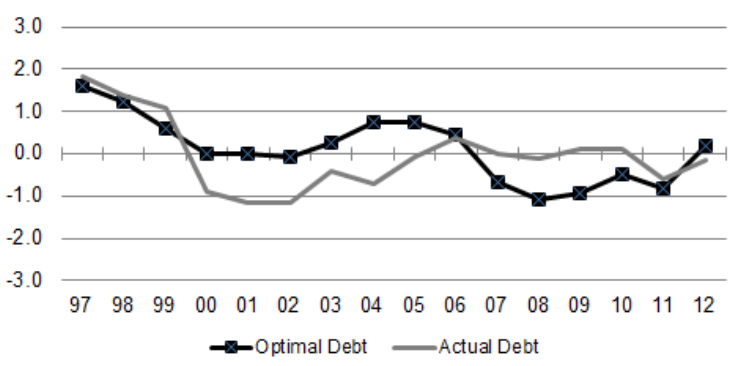

Finland Pohjola Bank

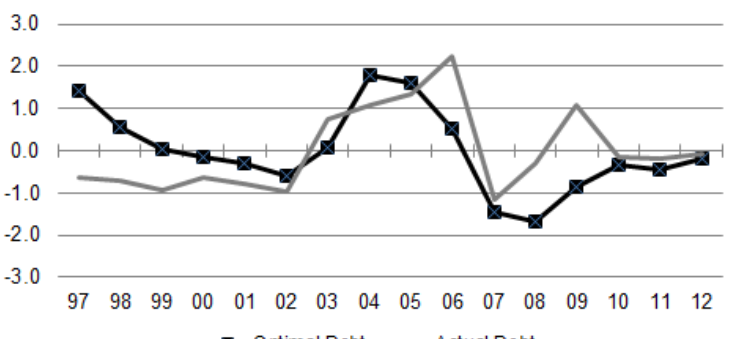

Figure A.2: Actual vs. Optimal Debt, country aggregates I
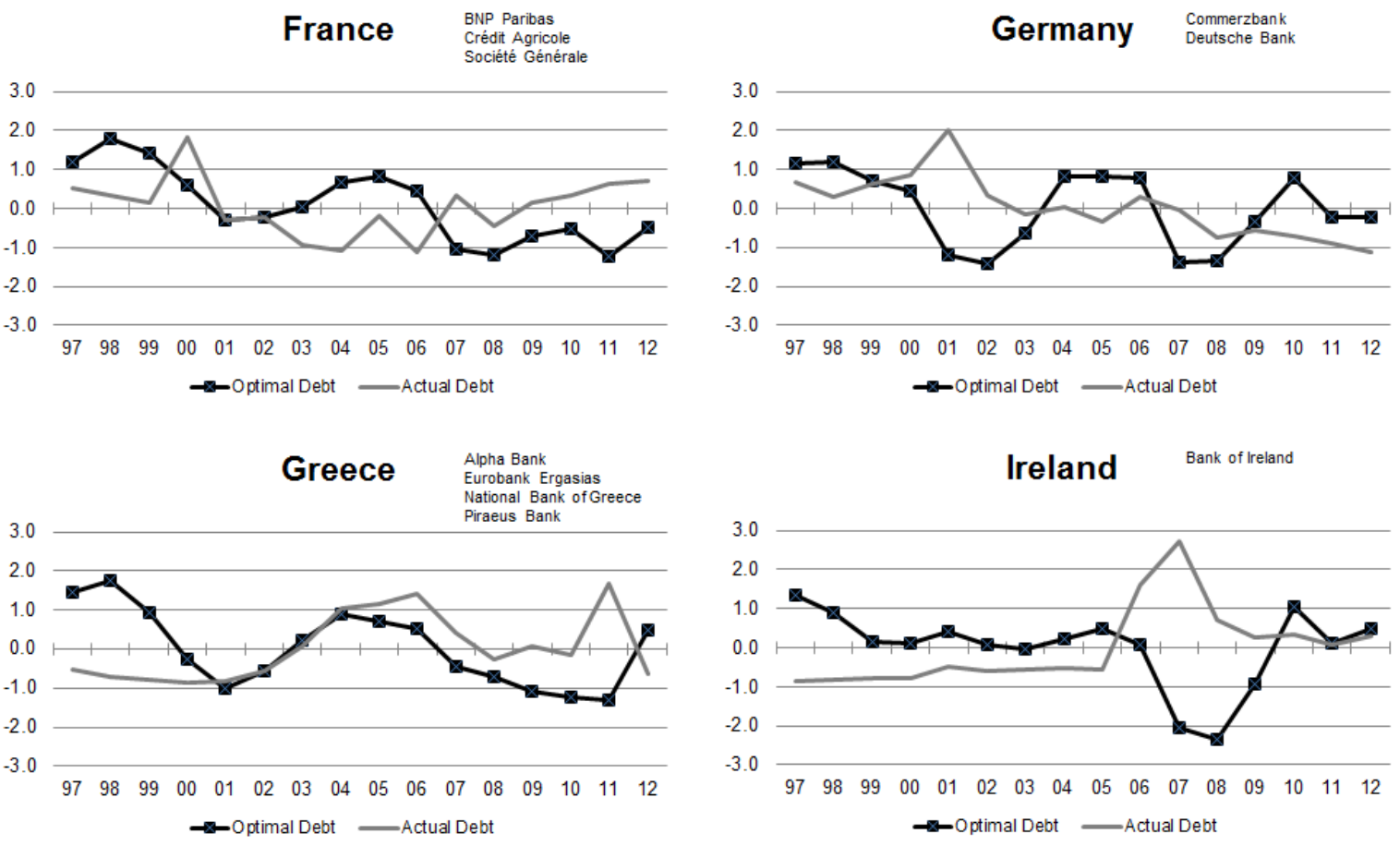

Figure A.3: Actual vs. Optimal Debt, country aggregates II 


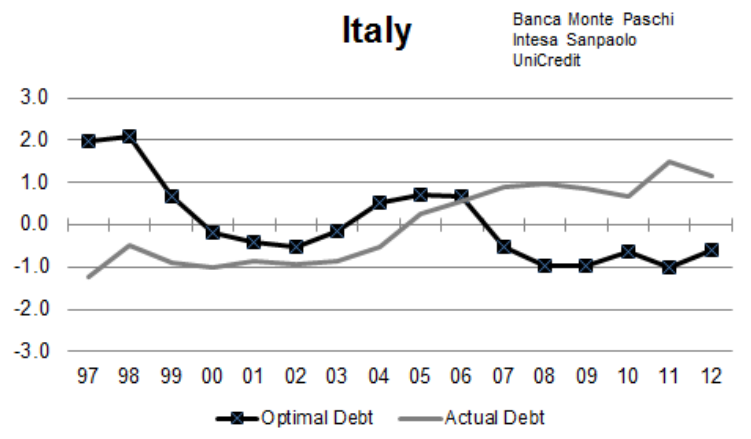

Netherlands ING Groep
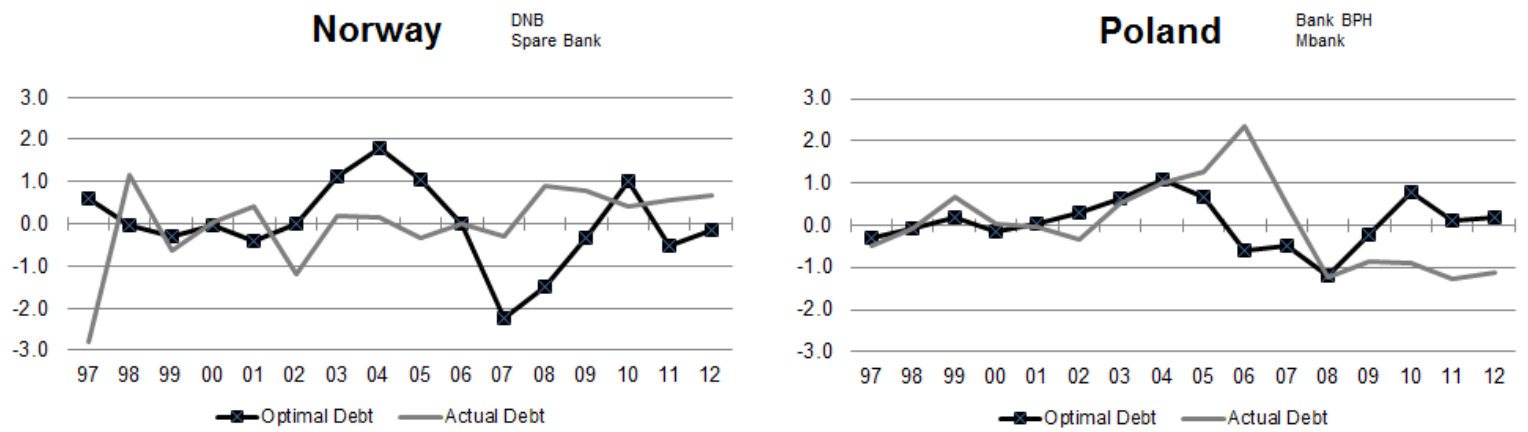

Figure A.4: Actual vs. Optimal Debt, country aggregates III
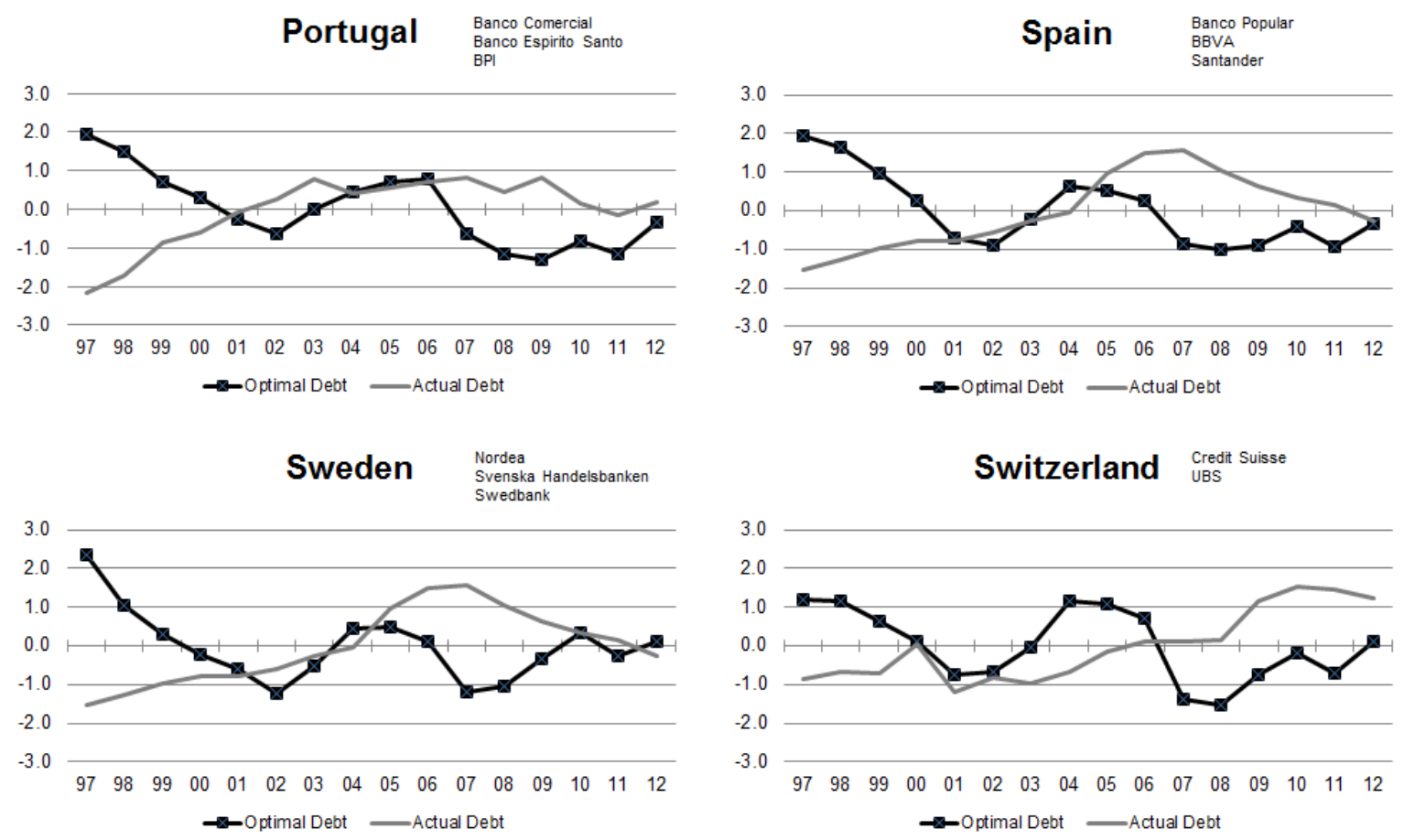

Figure A.5: Actual vs. Optimal Debt, country aggregates IV 


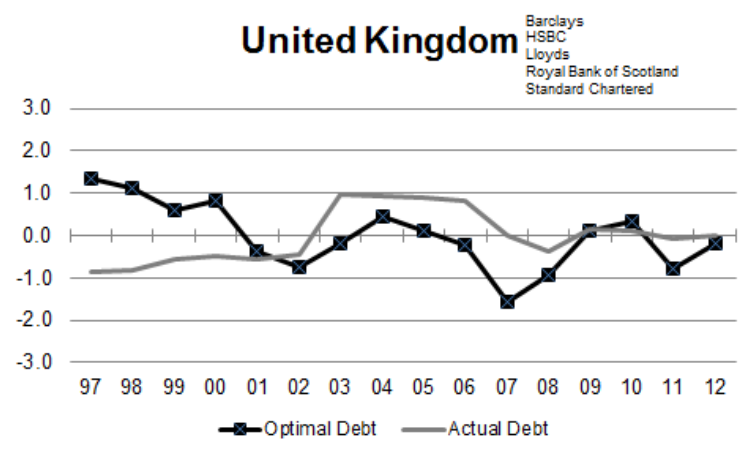

Figure A.6: Actual vs. Optimal Debt, country aggregates V 
TABLE A.3: Results of individual banks ${ }^{33}$

\begin{tabular}{|c|c|c|c|c|c|c|c|c|}
\hline & & rste Gr & & & Dexia & & & KBC \\
\hline & OD & $\mathrm{AD}$ & $\mathrm{A}-\mathrm{O}$ & OD & $\mathrm{AD}$ & $\mathrm{A}-\mathrm{O}$ & OD & $\mathrm{AD}$ \\
\hline 1997 & & -0.57 & & 0.99 & 2.09 & 1.10 & 2.00 & 1.66 \\
\hline 1998 & -0.19 & -0.49 & -0.30 & 1.11 & 1.94 & 0.83 & 1.28 & 1.22 \\
\hline 1999 & -0.28 & 3.54 & 3.82 & 1.08 & 0.73 & -0.35 & 0.29 & 1.33 \\
\hline 2000 & 0.10 & -0.37 & -0.47 & 0.79 & -1.22 & -2.01 & -0.86 & -0.52 \\
\hline 2001 & 0.43 & -0.39 & -0.82 & 0.31 & -1.21 & -1.52 & -0.54 & -1.08 \\
\hline 2002 & 0.72 & -0.52 & -1.24 & 0.09 & -1.24 & -1.33 & -0.38 & -1.03 \\
\hline 2003 & 1.20 & -0.29 & -1.49 & 0.17 & 0.30 & 0.13 & 0.36 & -1.35 \\
\hline 2004 & 1.56 & 0.01 & -1.55 & 0.56 & 0.21 & -0.35 & 0.97 & -1.69 \\
\hline 2005 & 1.38 & -0.53 & -1.91 & 0.54 & -0.17 & -0.71 & 0.90 & 0.03 \\
\hline 2006 & 0.57 & -0.46 & -1.03 & 0.46 & -0.36 & -0.82 & 0.42 & 0.98 \\
\hline 2007 & -1.42 & -0.42 & 1.00 & -0.19 & -0.56 & -0.37 & -1.05 & 0.45 \\
\hline 2008 & -1.70 & -0.11 & 1.59 & -0.42 & -0.45 & -0.03 & -1.71 & 0.17 \\
\hline 2009 & -0.70 & -0.39 & 0.31 & -0.62 & -0.16 & 0.46 & -1.29 & 0.42 \\
\hline 2010 & 0.13 & 0.52 & 0.39 & -0.65 & -0.13 & 0.52 & -0.38 & 0.23 \\
\hline 2011 & -1.06 & 0.35 & 1.41 & -1.85 & -0.57 & 1.28 & -0.36 & -0.60 \\
\hline 2012 & -0.74 & 0.13 & 0.87 & -2.37 & 0.81 & 3.18 & 0.35 & -0.22 \\
\hline & & ank Pol & & & P Pari & & $\mathrm{Cr}$ & dit Agr \\
\hline & OD & $\mathrm{AD}$ & $\mathrm{A}-\mathrm{O}$ & OD & $\mathrm{AD}$ & $\mathrm{A}-\mathrm{O}$ & OD & $\mathrm{AD}$ \\
\hline 1997 & 1.41 & -0.63 & -2.04 & 1.23 & 0.90 & -0.33 & & 1.30 \\
\hline 1998 & 0.56 & -0.72 & -1.28 & 2.25 & 0.51 & -1.74 & & 0.81 \\
\hline 1999 & 0.04 & -0.94 & -0.98 & 1.64 & -0.10 & -1.74 & & -0.11 \\
\hline 2000 & -0.14 & -0.63 & -0.49 & 0.55 & 0.84 & 0.29 & & -1.57 \\
\hline 2001 & -0.30 & -0.77 & -0.47 & -0.55 & -0.65 & -0.10 & & 1.06 \\
\hline 2002 & -0.60 & -0.97 & -0.37 & -0.72 & -0.15 & 0.57 & 1.12 & -0.02 \\
\hline 2003 & 0.06 & 0.76 & 0.70 & -0.60 & -0.79 & -0.19 & 1.02 & -1.50 \\
\hline 2004 & 1.80 & 1.07 & -0.73 & 0.19 & -0.94 & -1.13 & 1.15 & -1.70 \\
\hline 2005 & 1.62 & 1.35 & -0.27 & 0.44 & -0.52 & -0.96 & 1.08 & -0.26 \\
\hline 2006 & 0.53 & 2.24 & 1.71 & 0.16 & -2.39 & -2.55 & 0.63 & -0.46 \\
\hline 2007 & -1.45 & -1.16 & 0.29 & -1.03 & 0.39 & 1.42 & -0.79 & 1.07 \\
\hline 2008 & -1.69 & -0.29 & 1.40 & -1.03 & -1.06 & -0.03 & -1.13 & 0.39 \\
\hline 2009 & -0.87 & 1.09 & 1.96 & -0.55 & 0.81 & 1.36 & -0.74 & -0.56 \\
\hline 2010 & -0.33 & -0.15 & 0.18 & -0.41 & 1.04 & 1.45 & -0.57 & -0.37 \\
\hline 2011 & -0.46 & -0.18 & 0.28 & -1.07 & 1.09 & 2.16 & -1.38 & 0.80 \\
\hline 2012 & -0.19 & -0.07 & 0.12 & -0.50 & 1.03 & 1.53 & -0.39 & 1.13 \\
\hline & & utsche & & & pha $\mathrm{Ba}$ & & Eurc & ank Er \\
\hline & OD & $\mathrm{AD}$ & $\mathrm{A}-\mathrm{O}$ & OD & $\mathrm{AD}$ & $\mathrm{A}-\mathrm{O}$ & OD & $\mathrm{AD}$ \\
\hline 1997 & 1.22 & 0.54 & -0.68 & 1.34 & -0.88 & -2.22 & -0.23 & -1.15 \\
\hline 1998 & 1.30 & 0.28 & -1.02 & 1.38 & -0.85 & -2.23 & 2.32 & -1.20 \\
\hline 1999 & 0.96 & 0.93 & -0.03 & 0.78 & -0.85 & -1.63 & 1.28 & -1.20 \\
\hline 2000 & 0.69 & 1.08 & 0.39 & -0.17 & -0.82 & -0.65 & -0.26 & -1.07 \\
\hline 2001 & -1.05 & 2.41 & 3.46 & -1.15 & -0.82 & 0.33 & -0.56 & -0.86 \\
\hline 2002 & -1.50 & 0.60 & 2.10 & -0.54 & -0.61 & -0.07 & -0.30 & -0.75 \\
\hline 2003 & -0.73 & -0.05 & 0.68 & 0.41 & 0.33 & -0.08 & 0.33 & 0.18 \\
\hline 2004 & 0.64 & 0.25 & -0.39 & 1.09 & 1.61 & 0.52 & 0.77 & 1.51 \\
\hline 2005 & 0.72 & -0.16 & -0.88 & 0.71 & 1.11 & 0.40 & 0.62 & 1.36 \\
\hline 2006 & 0.75 & -0.10 & -0.85 & 0.45 & 2.34 & 1.89 & 0.44 & 1.66 \\
\hline 2007 & -1.54 & -0.90 & 0.64 & -0.49 & 0.65 & 1.14 & -0.54 & 0.84 \\
\hline 2008 & -1.30 & -1.56 & -0.26 & -0.79 & -0.73 & 0.06 & -0.86 & 0.41 \\
\hline 2009 & -0.25 & -0.44 & -0.19 & -1.23 & 0.07 & 1.30 & -1.24 & 0.65 \\
\hline 2010 & 0.80 & -0.65 & -1.45 & -1.43 & -0.14 & 1.29 & -1.42 & 0.08 \\
\hline 2011 & -0.47 & -1.08 & -0.61 & -1.30 & 0.36 & 1.66 & -1.05 & -0.30 \\
\hline 2012 & -0.25 & -1.15 & -0.90 & 0.94 & -0.75 & -1.69 & 0.70 & -0.16 \\
\hline & & $\mathrm{ak}$ of Ir & & Banc & Monte & aschi & Int & sa Sanp \\
\hline & OD & $\mathrm{AD}$ & $\mathrm{A}-\mathrm{O}$ & OD & $\mathrm{AD}$ & $\mathrm{A}-\mathrm{O}$ & OD & $\mathrm{AD}$ \\
\hline 1997 & 1.36 & -0.87 & -2.23 & & -1.37 & & 1.83 & -1.97 \\
\hline 1998 & 0.89 & -0.82 & -1.71 & & -1.21 & & 2.36 & -0.37 \\
\hline 1999 & 0.15 & -0.79 & -0.94 & & -1.27 & & 0.94 & -1.09 \\
\hline 2000 & 0.12 & -0.77 & -0.89 & 0.25 & -1.01 & -1.26 & -0.28 & -1.13 \\
\hline 2001 & 0.40 & -0.48 & -0.88 & 0.10 & -0.63 & -0.73 & -0.80 & -0.93 \\
\hline 2002 & 0.08 & -0.60 & -0.68 & -0.16 & -0.69 & -0.53 & -0.85 & -0.66 \\
\hline 2003 & -0.05 & -0.58 & -0.53 & 0.34 & -0.01 & -0.35 & -0.33 & -0.28 \\
\hline 2004 & 0.23 & -0.52 & -0.75 & 1.24 & -0.02 & -1.26 & 0.26 & -0.32 \\
\hline 2005 & 0.47 & -0.57 & -1.04 & 1.58 & 0.69 & -0.89 & 0.31 & 0.40 \\
\hline 2006 & 0.07 & 1.61 & 1.54 & 1.48 & 0.25 & -1.23 & 0.58 & 0.87 \\
\hline 2007 & -2.04 & 2.74 & 4.78 & 0.06 & 1.31 & 1.25 & -0.15 & 0.50 \\
\hline 2008 & -2.36 & 0.69 & 3.05 & -0.70 & 1.23 & 1.93 & -0.76 & 0.43 \\
\hline 2009 & -0.92 & 0.26 & 1.18 & -0.73 & -0.10 & 0.63 & -0.98 & 0.92 \\
\hline 2010 & 1.04 & 0.35 & -0.69 & -0.54 & -0.11 & 0.43 & -0.68 & 0.68 \\
\hline 2011 & 0.10 & 0.06 & -0.04 & -1.45 & 1.35 & 2.80 & -0.89 & 1.58 \\
\hline 2012 & 0.48 & 0.29 & -0.19 & -1.46 & 1.60 & 3.06 & -0.54 & 1.36 \\
\hline & & DNB & & & are $\mathrm{Ba}$ & & & ank BP \\
\hline & OD & $\mathrm{AD}$ & $\mathrm{A}-\mathrm{O}$ & OD & $\mathrm{AD}$ & $\mathrm{A}-\mathrm{O}$ & OD & $\mathrm{AD}$ \\
\hline 1997 & 0.65 & -2.93 & -3.58 & 0.04 & -1.21 & -1.25 & -0.05 & -0.15 \\
\hline 1998 & -0.01 & 1.35 & 1.36 & -0.29 & -1.67 & -1.38 & -0.04 & -0.65 \\
\hline 1999 & -0.26 & -0.59 & -0.33 & -0.68 & -1.46 & -0.78 & 0.19 & 0.65 \\
\hline 2000 & -0.03 & 0.07 & 0.10 & -0.49 & -0.71 & -0.22 & 0.42 & 0.28 \\
\hline 2001 & -0.38 & 0.44 & 0.82 & -1.21 & -0.15 & 1.06 & 0.76 & -0.05 \\
\hline 2002 & 0.05 & -1.23 & -1.28 & -0.87 & -0.73 & 0.14 & 0.82 & -0.59 \\
\hline 2003 & 1.14 & 0.23 & -0.91 & 0.26 & -0.64 & -0.90 & 0.85 & 0.48 \\
\hline 2004 & 1.77 & 0.15 & -1.62 & 1.96 & -0.10 & -2.06 & 1.12 & 1.17 \\
\hline 2005 & 1.03 & -0.37 & -1.40 & 0.93 & 0.44 & -0.49 & 0.49 & 1.25 \\
\hline 2006 & -0.01 & -0.01 & 0.00 & -0.01 & 0.46 & 0.47 & -1.35 & 2.52 \\
\hline 2007 & -2.24 & -0.34 & 1.90 & -1.94 & 0.93 & 2.87 & -2.69 & -0.59 \\
\hline 2008 & -1.53 & 0.85 & 2.38 & -0.76 & 1.86 & 2.62 & -1.06 & -0.73 \\
\hline 2009 & -0.38 & 0.78 & 1.16 & 0.36 & 0.88 & 0.52 & 0.45 & -0.71 \\
\hline 2010 & 1.00 & 0.36 & -0.64 & 1.30 & 1.01 & -0.29 & 0.78 & -0.90 \\
\hline 2011 & -0.57 & 0.55 & 1.12 & 0.51 & 0.50 & -0.01 & -0.50 & -1.02 \\
\hline 2012 & -0.24 & 0.68 & 0.92 & 0.90 & 0.61 & -0.29 & -0.20 & -0.98 \\
\hline
\end{tabular}

\footnotetext{
${ }^{33} \mathrm{OD}=$ optimal debt, $\mathrm{AD}=$ actual debt, $\mathrm{A}-\mathrm{O}=($ actual - optimal debt $)$
} 


\begin{tabular}{|c|c|c|c|c|c|c|c|c|c|c|c|c|c|c|c|}
\hline & \multicolumn{3}{|c|}{ Banco Espirito Santo ${ }^{34}$} & \multicolumn{3}{|c|}{ BPI } & \multicolumn{3}{|c|}{ Banco Popular } & \multicolumn{3}{|c|}{ BBVA } & \multicolumn{3}{|c|}{ Santander } \\
\hline & OD & $\mathrm{AD}$ & $\mathrm{A}-\mathrm{O}$ & OD & $\mathrm{AD}$ & $\mathrm{A}-\mathrm{O}$ & OD & $\mathrm{AD}$ & $\mathrm{A}-\mathrm{O}$ & OD & $\mathrm{AD}$ & $\mathrm{A}-\mathrm{O}$ & OD & $\mathrm{AD}$ & $\mathrm{A}-\mathrm{O}$ \\
\hline 1997 & 2.26 & -2.22 & -4.48 & 1.87 & -2.07 & -3.94 & 1.43 & -1.45 & -2.88 & 2.18 & -1.74 & -3.92 & 1.87 & -1.30 & -3.17 \\
\hline 1998 & 1.52 & -1.48 & -3.00 & 1.36 & -1.06 & -2.42 & 0.92 & -1.10 & -2.02 & 1.51 & -1.53 & -3.04 & 2.03 & -0.97 & -3.00 \\
\hline 1999 & 0.20 & -0.89 & -1.09 & 0.22 & -1.19 & -1.41 & -0.07 & -0.64 & -0.57 & 0.97 & -1.40 & -2.37 & 1.18 & -0.67 & -1.85 \\
\hline 2000 & -0.44 & -0.48 & -0.04 & -0.49 & -1.08 & -0.59 & 0.14 & -1.33 & -1.47 & 0.31 & -0.60 & -0.91 & 0.22 & -0.91 & -1.13 \\
\hline 2001 & -0.21 & 0.08 & 0.29 & -0.45 & -0.42 & 0.03 & 0.35 & -1.03 & -1.38 & -0.63 & -0.64 & -0.01 & -1.00 & -0.92 & 0.08 \\
\hline 2002 & -0.08 & -0.07 & 0.01 & -0.21 & -0.02 & 0.19 & 0.37 & -0.92 & -1.29 & -1.18 & -0.50 & 0.68 & -0.95 & -0.58 & 0.37 \\
\hline 2003 & 0.33 & 1.49 & 1.16 & 0.44 & 0.33 & -0.11 & 0.37 & -0.14 & -0.51 & -0.43 & -0.25 & 0.18 & -0.18 & -0.27 & -0.09 \\
\hline 2004 & 0.15 & 0.63 & 0.48 & 0.71 & 0.18 & -0.53 & 0.60 & 0.17 & -0.43 & 0.52 & 0.07 & -0.45 & 0.68 & -0.18 & -0.86 \\
\hline 2005 & 0.65 & 1.29 & 0.64 & 1.06 & 0.51 & -0.55 & 0.85 & 1.56 & 0.71 & 0.69 & 0.92 & 0.23 & 0.34 & 0.91 & 0.57 \\
\hline 2006 & 1.02 & 0.58 & -0.44 & 0.79 & 1.12 & 0.33 & 0.51 & 0.45 & -0.06 & 0.27 & 1.31 & 1.04 & 0.17 & 1.83 & 1.66 \\
\hline 2007 & -0.49 & 0.63 & 1.12 & -0.94 & 0.96 & 1.90 & -1.18 & 1.43 & 2.61 & -1.04 & 0.95 & 1.99 & -0.63 & 2.04 & 2.67 \\
\hline 2008 & -1.02 & 0.74 & 1.76 & -1.47 & 0.17 & 1.64 & -2.06 & 1.02 & 3.08 & -1.25 & 1.16 & 2.41 & -0.72 & 0.98 & 1.70 \\
\hline 2009 & -1.35 & 0.68 & 2.03 & -1.39 & 2.01 & 3.40 & -2.04 & 0.59 & 2.63 & -0.91 & 1.12 & 2.03 & -0.79 & 0.40 & 1.19 \\
\hline 2010 & -0.74 & 0.24 & 0.98 & -1.02 & 0.23 & 1.25 & -0.52 & 0.47 & 0.99 & -0.22 & 0.62 & 0.84 & -0.50 & 0.19 & 0.69 \\
\hline 2011 & -1.36 & -0.55 & 0.81 & -0.78 & -0.01 & 0.77 & -0.17 & 1.11 & 1.28 & -0.76 & 0.30 & 1.06 & -1.12 & 0.02 & 1.14 \\
\hline \multirow[t]{3}{*}{2012} & -0.44 & -0.67 & -0.23 & 0.28 & 0.35 & 0.07 & 0.50 & -0.19 & -0.69 & -0.04 & 0.20 & 0.24 & -0.62 & -0.56 & 0.06 \\
\hline & \multicolumn{3}{|c|}{ Nordea } & \multicolumn{3}{|c|}{ Svenska Handelsb. } & \multicolumn{3}{|c|}{ Swedbank } & \multicolumn{3}{|c|}{ Credit Suisse } & \multicolumn{3}{|c|}{ UBS } \\
\hline & OD & $\mathrm{AD}$ & $\mathrm{A}-\mathrm{O}$ & OD & $\mathrm{AD}$ & $\mathrm{A}-\mathrm{O}$ & OD & $\mathrm{AD}$ & $\mathrm{A}-\mathrm{O}$ & OD & $\mathrm{AD}$ & $\mathrm{A}-\mathrm{O}$ & OD & $\mathrm{AD}$ & A-O \\
\hline 1997 & 2.72 & 1.42 & -1.30 & 2.45 & -1.11 & -3.56 & 1.95 & 0.42 & -1.53 & 2.01 & -0.89 & -2.90 & 0.58 & -0.86 & -1.44 \\
\hline 1998 & 1.32 & 0.70 & -0.62 & 0.93 & 0.53 & -0.40 & 0.63 & 0.65 & 0.02 & 1.47 & -0.57 & -2.04 & 0.95 & -0.72 & -1.67 \\
\hline 1999 & 0.73 & 1.31 & 0.58 & 0.43 & 0.52 & 0.09 & -0.47 & 0.27 & 0.74 & 0.66 & -0.84 & -1.50 & 0.64 & -0.59 & -1.23 \\
\hline 2000 & -0.23 & 1.38 & 1.61 & 0.19 & -1.21 & -1.40 & -0.72 & -0.53 & 0.19 & 0.15 & -1.24 & -1.39 & 0.07 & 1.33 & 1.26 \\
\hline 2001 & -0.63 & 1.29 & 1.92 & -0.38 & -1.42 & -1.04 & -0.79 & 0.60 & 1.39 & -1.29 & -0.90 & 0.39 & -0.30 & -1.47 & -1.17 \\
\hline 2002 & -1.43 & 0.06 & 1.49 & -1.25 & -1.14 & 0.11 & -0.72 & 0.30 & 1.02 & -1.18 & -0.63 & 0.55 & -0.37 & -0.96 & -0.59 \\
\hline 2003 & -0.63 & -0.32 & 0.31 & -0.70 & -0.59 & 0.11 & -0.11 & 0.11 & 0.22 & -0.59 & -0.51 & 0.08 & 0.24 & -1.20 & -1.44 \\
\hline 2004 & 0.40 & -0.50 & -0.90 & 0.33 & -0.48 & -0.81 & 0.70 & -1.32 & -2.02 & 1.01 & -0.37 & -1.38 & 1.23 & -0.81 & -2.04 \\
\hline 2005 & 0.54 & -0.29 & -0.83 & 0.27 & -0.91 & -1.18 & 0.64 & -0.92 & -1.56 & 0.79 & -0.29 & -1.08 & 1.27 & -0.09 & -1.36 \\
\hline 2006 & 0.22 & -0.21 & -0.43 & -0.22 & 0.08 & 0.30 & 0.28 & -1.34 & -1.62 & 0.67 & 0.06 & -0.61 & 0.72 & 0.12 & -0.60 \\
\hline 2007 & -0.81 & -0.38 & 0.43 & -1.81 & 0.79 & 2.60 & -1.54 & -1.52 & 0.02 & -0.72 & -0.10 & 0.62 & -1.83 & 0.21 & 2.04 \\
\hline 2008 & -0.65 & 0.56 & 1.21 & -1.26 & 0.26 & 1.52 & -1.74 & -1.11 & 0.63 & -0.65 & 0.21 & 0.86 & -2.20 & 0.08 & 2.28 \\
\hline 2009 & -0.36 & -1.21 & -0.85 & -0.14 & 1.10 & 1.24 & -0.53 & 0.63 & 1.16 & -0.47 & 0.82 & 1.29 & -1.00 & 1.48 & 2.48 \\
\hline 2010 & -0.08 & -1.28 & -1.20 & 0.62 & 1.75 & 1.13 & 1.23 & 0.64 & -0.59 & -0.51 & 1.93 & 2.44 & 0.07 & 1.19 & 1.12 \\
\hline 2011 & -0.78 & -1.29 & -0.51 & 0.05 & 0.44 & 0.39 & 0.66 & 1.65 & 0.99 & -1.19 & 1.56 & 2.75 & -0.37 & 1.36 & 1.73 \\
\hline \multirow[t]{3}{*}{2012} & -0.35 & -1.23 & -0.88 & 0.50 & 1.37 & 0.87 & 0.51 & 1.46 & 0.95 & -0.16 & 1.74 & 1.90 & 0.30 & 0.94 & 0.64 \\
\hline & \multicolumn{3}{|c|}{ Barclays } & \multicolumn{3}{|c|}{ HSBC } & & Lloyds & & & RBS & & Stan & $\mathrm{rd} \mathrm{Ch}$ & tered \\
\hline & OD & $\mathrm{AD}$ & $\mathrm{A}-\mathrm{O}$ & OD & $\mathrm{AD}$ & $\mathrm{A}-\mathrm{O}$ & OD & $\mathrm{AD}$ & $\mathrm{A}-\mathrm{O}$ & OD & $\mathrm{AD}$ & $\mathrm{A}-\mathrm{O}$ & OD & $\mathrm{AD}$ & $\mathrm{A}-\mathrm{O}$ \\
\hline 1997 & 1.40 & -1.24 & -2.64 & 1.13 & -0.55 & -1.68 & 2.12 & -1.02 & -3.14 & 0.50 & -0.85 & -1.35 & -0.24 & -0.78 & -0.54 \\
\hline 1998 & 1.06 & -1.11 & -2.17 & 1.37 & -0.46 & -1.83 & 1.09 & -1.04 & -2.13 & 1.42 & -0.46 & -1.88 & -0.38 & -0.90 & -0.52 \\
\hline 1999 & 0.22 & -0.95 & -1.17 & 1.53 & -0.41 & -1.94 & -0.64 & -0.65 & -0.01 & 1.91 & -0.10 & -2.01 & -0.10 & -0.60 & -0.50 \\
\hline 2000 & 0.81 & 0.12 & -0.69 & 1.19 & -0.43 & -1.62 & -0.57 & -0.64 & -0.07 & 1.89 & -0.95 & -2.84 & -0.48 & -0.56 & -0.08 \\
\hline 2001 & -0.10 & 0.25 & 0.35 & -0.68 & -0.62 & 0.06 & -0.84 & -0.75 & 0.09 & 0.66 & -0.80 & -1.46 & -1.53 & -0.81 & 0.72 \\
\hline 2002 & -0.54 & 0.43 & 0.97 & -0.90 & -0.46 & 0.44 & -1.18 & -0.52 & 0.66 & -0.19 & -0.89 & -0.70 & -1.41 & -0.71 & 0.70 \\
\hline 2003 & -0.46 & 1.67 & 2.13 & 0.28 & 2.24 & 1.96 & -1.24 & -0.37 & 0.87 & -0.37 & -0.68 & -0.31 & -0.14 & -0.63 & -0.49 \\
\hline 2004 & 0.60 & 1.50 & 0.90 & 0.76 & 2.15 & 1.39 & -0.03 & -0.46 & -0.43 & -0.21 & -0.71 & -0.50 & 1.30 & -0.60 & -1.90 \\
\hline 2005 & 0.58 & -0.55 & -1.13 & -0.13 & 0.76 & 0.89 & 0.45 & -0.51 & -0.96 & -0.25 & 2.20 & 2.45 & 1.22 & 3.08 & 1.86 \\
\hline 2006 & -0.03 & -0.62 & -0.59 & -0.76 & 1.02 & 1.78 & 0.22 & -0.52 & -0.74 & -0.11 & 2.28 & 2.39 & 1.45 & 0.81 & -0.64 \\
\hline 2007 & -2.58 & -0.69 & 1.89 & -1.90 & 0.07 & 1.97 & -1.30 & 0.15 & 1.45 & -0.67 & 0.06 & 0.73 & -0.62 & 0.70 & 1.32 \\
\hline 2008 & -1.26 & -0.87 & 0.39 & -1.14 & -0.52 & 0.62 & 0.08 & -0.03 & -0.11 & -1.09 & -0.24 & 0.85 & 0.13 & 0.02 & -0.11 \\
\hline 2009 & -0.15 & 0.17 & 0.32 & 0.08 & -0.53 & -0.61 & 1.26 & 1.70 & 0.44 & -1.04 & 0.46 & 1.50 & 0.85 & 0.25 & -0.60 \\
\hline 2010 & 0.80 & 0.02 & -0.78 & 0.05 & -0.64 & -0.69 & 0.85 & 1.83 & 0.98 & -0.68 & 0.65 & 1.33 & 1.52 & -0.01 & -1.53 \\
\hline 2011 & -0.90 & -0.15 & 0.75 & -0.81 & -0.69 & 0.12 & -0.72 & 1.64 & 2.36 & -1.01 & 0.03 & 1.04 & -0.42 & 0.27 & 0.69 \\
\hline 2012 & 0.56 & 2.02 & 1.46 & -0.06 & -0.93 & -0.87 & 0.45 & 1.18 & 0.73 & -0.74 & -0.01 & 0.73 & -1.15 & 0.47 & 1.62 \\
\hline
\end{tabular}

${ }^{34}$ Note that Banco Espirito Santo has been split into a "bad bank" and a "good bank", now called Novo Banco, in August 2014. 


\section{References}

Admati, A. and Hellwig, M. (2013), The Banker's New Clothes: What's Wrong With Banking and What to Do About It, Princeton: Princeton University Press.

Adrian, T. and Shin, H. S. (2009), 'Money, Liquidity, and Monetary Policy', American Economic Review 99(2), 600-605.

Alessandro, C. and João, S. (2006), 'Output and Inflation Responses to Credit Shocks: Are There Threshold Effects in the Euro Area?', Studies in Nonlinear Dynamics \& Econometrics 10(2), 1-21.

Alessi, L. and Detken, C. (2014), Identifying Excessive Credit Growth and Leverage, Technical report, European Central Bank, Working paper series, No. 1723, August 2014.

Avdjiev, S. and Zeng, Z. (2014), 'Credit growth, monetary policy and economic activity in a three-regime tvar model', Applied Economics 46(24), 2936-2951.

Balke, N. S. (2000), 'Credit and Economic Activity: Credit Regimes and Nonlinear Propagation of Shocks', The Review of Economics and Statistics 82(2), 344-349.

Bassett, W. F., Chosak, M. B., Driscoll, J. C. and Zakrajsek, E. (2014), 'Changes in bank lending standards and the macroeconomy', Journal of Monetary Economics 62(C), 2340 .

Bernanke, B. S., Gertler, M. and Gilchrist, S. (1999), The Financial Accelerator in a Quantitative Business Cycle Framework, in J. B. Taylor and M. Woodford, eds, 'Handbook of Macroeconomics', Vol. 1 of Handbook of Macroeconomics, Elsevier, chapter 21, pp. 1341-1393.

Bijsterbosch, M. and Falagiarda, M. (2014), Credit supply dynamics and economic activity in euro area countries: A time-varying parameter var analysis, Technical report, ECB Working Paper No. 1714.

Brunnermeier, M. K. (2009), 'Deciphering the Liquidity and Credit Crunch 2007-2008', Journal of Economic Perspectives 23(1), 77-100.

Brunnermeier, M. K. and Oehmke, M. (2013), Bubbles, Financial Crises, and Systemic Risk, in G. M. Constantinides, M. Harris and R. M. Stulz, eds, 'Handbook of the Economics of Finance', Vol. 2, Part B, Elsevier, Amsterdam, chapter 18, pp. 12211288.

Brunnermeier, M. K. and Sannikov, Y. (2014), 'A Macroeconomic Model with a Financial Sector', American Economic Review 104(2), 379-421.

Christiano, L. and Ikeda, D. (2013), Leverage restrictions in a business cycle model, Working Paper 18688, National Bureau of Economic Research. 
Clerc, L., Dervitz, A., Mendicino, C., Moen, S., Nikolov, K., Stracca, L., Suarez, J. and Verdoulakis, A. (2014), Capital Regulation in a Macroeconomic Model with Three Layers of Default, Technical report, ESCB Macro-prudential Research Network, ECB, Frankfurt.

de Bondt, G., Maddaloni, A., Peydró, J.-L. and Scopel, S. (2010), The euro area Bank Lending Survey matters: empirical evidence for credit and output growth, Working Paper Series 1160, European Central Bank.

De Grauwe, P. and Macchiarelli, C. (2013), Animal Spirits and Credit Cycles, Technical report, CESifo Working Paper Series No. 4480.

Gerali, A., Neri, S., Sessa, L. and Signoretti, F. M. (2010), 'Credit and Banking in a DSGE Model of the Euro Area', Journal of Money, Credit and Banking 42(s1), 107-141.

Gilchrist, S. and Mojon, B. (2014), Credit risk in the euro area, Working Paper 20041, National Bureau of Economic Research.

Gilchrist, S., Yankov, V. and Zakrajsek, E. (2009), 'Credit market shocks and economic fluctuations: Evidence from corporate bond and stock markets', Journal of Monetary Economics 56(4), 471-493.

Gilchrist, S. and Zakrajšek, E. (2012), 'Credit Spreads and Business Cycle Fluctuations', American Economic Review 102(4), 1692-1720.

Goodhart, C. A., Kashyap, A. K., Tsomocos, D. P. and Vardoulakis, A. P. (2012), Financial regulation in general equilibrium, Working Paper 17909, National Bureau of Economic Research.

Grüne, L. and Pannek, J. (2011), Nonlinear Model Predictive Control, Springer, Heidelberg.

Grüne, L. and Semmler, W. (2004), 'Using Dynamic Programming with Adaptive Grid Scheme for Optimal Control Problems in Economics', Journal of Economic Dynamics and Control 28(12), 2427-2456.

Grüne, L., Semmler, W. and Stieler, M. (2013), Using Nonlinear Model Predictive Control for Dynamic Decision Problems in Economics, Technical report, SSRN eLibrary.

Helbling, T., Huidrom, R., Kose, M. A. and Otrok, C. (2011), 'Do credit shocks matter? a global perspective', European Economic Review 55(3), 340 - 353. Special Issue: Advances in International Macroeconomics: Lessons from the Crisis.

Hristov, N., Huelsewig, O. and Wollmershaeuser, T. (2012), 'Loan supply shocks during the financial crisis: Evidence for the euro area', Journal of International Money and Finance 31(3), 569 - 592. Financial Stress in the Eurozone.

Koop, G., Pesaran, M. H. and Potter, S. M. (1996), 'Impulse Response Analysis in Nonlinear Multivariate Models', Journal of Econometrics 74(1), 119-147. 
Basel Committee on Banking Supervision (August 2010), An assessment of the long-term economic impact of stronger capital and liquidity requirements, Technical report, Bank for International Settlements.

Mittnik, S. and Semmler, W. (2013), 'The Real Consequences of Financial Stress', Journal of Economic Dynamics \& Control 37(8), 1479-1499.

Proano, C. R., Schoder, C. and Semmler, W. (2014), 'Financial Stress, Sovereign Debt and Economic Activity in Industrialized Countries: Evidence from Dynamic Threshold Regressions', Journal of International Money and Finance 45, 17-37.

Schleer, F. (2013), Finding Starting-Values for Maximum Likelihood Estimation of Vector STAR models, Discussion Paper 13-076, ZEW Mannheim.

Schleer, F. and Semmler, W. (2013), Financial Sector and Output Dynamics in the Euro Area: Non-linearities Reconsidered, Discussion Paper 13-068, ZEW Mannheim.

Serwa, D. (2012), 'Banking crises and nonlinear linkages between credit and output', Applied Economics 44(8), 1025-1040.

Stein, J. L. (2003), Stochastic Optimal Control Modeling of Debt Crises, CESifo Working Paper Series 1043, CESifo Group Munich.

Stein, J. L. (2012), Stochastic Optimal Control and the U.S. Financial Debt Crisis, Springer, Heidelberg/New York.

Teräsvirta, T. and Yang, Y. (2014a), Linearity and Misspecification Tests for Vector Smooth Transition Regression Models, Research Paper 2014-4, CREATES, Aarhus University.

Teräsvirta, T. and Yang, Y. (2014b), Specification, Estimation and Evaluation of Vector Smooth Transition Autoregressive Models with Applications, Research Paper 2014-8, CREATES, Aarhus University. 